\title{
ADA Title III: A Fragile Compromise
}

\section{Ruth Colker $\dagger$}

Title III of the Americans with Disabilities Act' (ADA Title III) protects individuals with disabilities from discrimination at places of public accommodation. ${ }^{2}$ Such discrimination takes the form of outright exclusion, with policies and eligibility criteria that have a disparate impact against individuals with disabilities, as well as physical barriers that impede accessibility. ${ }^{3}$

Although the employment title of the ADA (Title I) ${ }^{4}$ has received the most public attention, ADA Title III is equally important because it applies to all individuals with disabilities, irrespective of whether they are sufficiently qualified to engage in employment." Because the definition of "public accommodation" under ADA Title III is broad, ${ }^{6}$ the title requires accessibility and nondiscrimination at entities that individuals visit on a frequent basis in order to obtain the basic essentials like food, lodging, and health care. The title also extends to entities that individuals visit to enhance the quality of their lives, such as restaurants, hotels, and places of amusement and recreation. ADA Title III therefore plays an enormously important role in the integration of individuals with disabilities into society in general.

However, the broad coverage of ADA Title III came at a price-as part of a

(C) Ruth Colker 2000.

$\dagger$ Heck-Faust Chair in Constitutional Law, Ohio State University College of Law. I would like to thank the USX Foundation for supporting the research that underlies this article. I also would like to thank my many research assistants who performed excellent research for this article: Amanda Dine-Gamble, Leslie Kerns, Beth Paxton, and Theodore Wern. I would like to thank the following people who offered feedback on an earlier draft: Samuel Bagenstos, Jim Brudney, Chai Feldblum, Joseph William Singer, and Bonmie Poitras Tucker. Finally, I would like to thank the Berkeley symposium participants who were a wonderful and helpful audience.

1. 42 U.S.C. $\S \S 12181-12189$ (1994).

2. "No individual shall be discriminated against on the basis of disability in the full and equal enjoyment of the goods, services, facilities, privileges, advantages or accommodations of any place of public accommodation by any person who owns, leases (or leases to), or operates a place of public accommodation." Id. § 12182(a).

3. See id. $\S 12182(\mathrm{~b})(2)(\mathrm{A}-\mathrm{D})$ (defining specific prohibitions that constitute "discrimination").

4. See id. $\S 12101-12117$ (prohibiting employment discrimination).

5. See id. $\$ 12111$ (8) (defining "qualified individual with a disability" as "an individual with a disability who, with or without reasonable accommodation, can perform the essential functions of the employment position that such individual holds or desires").

6. The definition of "public accommodation" covers twelve categories of entities, ranging from Laundromats to bowling alleys. See 42 U.S.C. $\$ 12181$ (7) (defining "public accommodations"). In addition, the term "commercial facilities" is defined as "facilities (a) that are intended for nonresidential use; and (b) whose operations will affect commerce." Id. \$12181(2). Prohibitions against discrimination do not generally apply to all commercial facilities. See id. $\S 12182(\mathrm{a})$. The accessibility requirements for new construction and alterations, however, do apply to commercial facilities as well as public accommodations. See $i d . \S 12183$. The definition of disability is also arguably broad. See id. § 12102(2) ("The term 'disability' means, with respect to an individual - (A) a physical or mental impairment that substantially limits one or more of the major life activities of such individual; (B) a record of such an impairment; or (C) being regarded as having such an impairment."). 
"fragile compromise." In return for a broad list of covered entities, civil rights advocates agreed to a limited set of remedies under ADA Title III. When private parties bring suit under ADA Title III, they are only able to obtain injunctive relief and are not able to obtain monetary damages. ${ }^{8}$ This compromise was modeled after an agreement reached in 1964 when Title II of the Civil Rights Act of $1964^{9}$ (CRA Title II) was enacted to prohibit racial discrimination at places of public accommodation. CRA Title II, like ADA Title III, only permits private individuals to seek injunctive relief. ${ }^{10}$ Unlike ADA Title III, however, CRA Title II only covers a few categories of public accommodations." Proponents of the ADA were therefore able to obtain broader coverage than previous civil rights activists had been able to obtain under CRA Title II, but they were not able to move beyond the limited set of remedies enacted under CRA Title II. In order to seek broader remedies under ADA Title III than under CRA Title II, disability rights advocates argued for Congress to consider a different legislative model-the Fair Housing Act (FHA) ${ }^{12}$ which prohibits discrimination in the sale or rental of housing to any buyer or renter. Enacted in 1968 to prohibit housing discrimination on the basis of race, the FHA has always contained compensatory and punitive damages as a potential source for relief. ${ }^{13}$ In 1988, when the Act was amended to provide protection against discrimination for individuals with disabilities, ${ }^{14}$ it was also amended to remove the cap on punitive damages, ${ }^{15}$ as well as to provide for

7. See infra note 47 (quoting remarks from Senator Harkin).

8. See 42 U.S.C. $\$ 12188$ (a)(2) (1994) (providing for injunctive relief in private suits by affected parties); see also id. $\S 12188$ (b) (providing for enforcement by the Attomey General with potential civil penalties ranging from $\$ 50,000$ to $\$ 100,000$ per violation).

9. Id. $\$ 2000 \mathrm{a}-6$.

10. See id. $\S 2000 \mathrm{a}-3$ (permitting civil action for preventive relief by a private party and intervention by the Attomey General "if [the Attorney General] certifies that the case is of general public imporance.").

11. CRA Title II covers places that provide lodging to transient guests, facilities principally engaged in selling food for consumption, gasoline stations, and places of exhibition or entertainment. See id. § 2000a(b).

12. Fair Housing Act of 1968,42 U.S.C. $\$ \$ 3602$ (h) (1994).

13. See id. The FHA was originally enacted as Pub. L. No. $90-284, \S 812(\mathrm{c}), 82$ Stat. 73,88 (codified as amended at 42 U.S.C. $\S \S 3613-14$ (1994)).

14. See Fair Housing Amendments Act of 1988, Pub. L. No. 100-430, § 5(b)-6(a), 102 Stat. 1619-22 (codified as amended at 42 U.S.C. $\$ \$ 3602-04$ (1994)) (amending the definitions section to include "handicap" and adding prohibition against discrimination on the basis of handicap in the sale or rental of housing to any buyer or renter).

15. When originally enacted, the Fair Housing Act provided the following provision for relief:

The court may grant as relief, as it deems appropriate, any permanent or temporary injunction, temporary restraining order, or other order, and may award to the plaintiff actual damages and not more than $\$ 1,000$ punitive damages, together with court costs and reasonable attorney fees in the case of a prevailing plaintiff: Provided, That the said plaintiff in the opinion of the court is not financially able to assume said attorney's fees.

Fair Housing Act, Pub. L. No. 90-284, § 812, 82 Stat. 73, 88 (1968).

When amended in 1988, the relief provision for private parties who brought civil actions was moved to section 3613. The amended and renumbered provision provides:

(1) In a civil action under subsection (a), if the cour finds that a discriminatory housing practice has occurred or is about to occur, the court may award to the plaintiff actual and punitive damages, and subject to subsection (d) of this section, may grant as relief, as the court deems appropriate, any permanent or temporary injunction, temporary restraining order, or other order (including an order enjoining the defendant from engaging in such practice or ordering such affirmative action as may be appropriate) ... (2) In a civil action under subsection (a) of this section, the court, in its discretion, may allow the prevailing 
mandatory enforcement by the Attorney General [AG] when the Secretary of Housing and Urban Development [HUD] "determines that reasonable cause exists to believe that a discriminatory housing practice has occurred or is about to occur",16 and a complainant chooses judicial rather than administrative relief. Senator Harkin argued that the FHA compensatory and punitive damages remedial scheme, rather than the CRA Title II injunctive remedial scheme, was appropriate for ADA Title III. ${ }^{17}$ In the end, however, the limited relief available under CRA Title II prevailed in a spirit of compromise. ${ }^{18}$

When legislation is being considered by Congress, compromises are an essential ingredient of enactment. In this context, ADA proponents traded expanded coverage for limited relief. This compromise, however, was reached as part of a "one step at a time" approach, reserving for another day the question of whether this limited scheme of relief would be effective. Because CRA Title II has been relatively effective in vindicating the rights of racial minorities who are denied access to public accommodations, this compromise seemed like a reasonable one when the ADA was enacted in 1990. Proponents of ADA Title III could claim victory because they obtained broader coverage than that which exists under CRA Title II, with equivalent remedies.

Now that ten years have passed since the enactment of ADA Title III, it is a good time to assess the success of this compromise. This paper argues that ADA Title III has been less successful than was originally hoped. Due in part to its limited avenue for relief, ${ }^{19}$ ADA Title III has spawned few lawsuits. In addition, courts have rendered exceedingly narrow interpretations of their already limited authority to grant injunctive relief. The second problem feeds into the first. By narrowly interpreting an already limited remedy, the courts have further reduced

party, other than the United States, a reasonable attomey's fee and costs. The United States shall be liable for such fees and costs to the same extent as a private person.

Pub. L. No. 100-430, $\S 813$ (c), 102 Stat. 1619, 1633-34 (1988) (codified as amended at 42 U.S.C. $\S 3613(\mathrm{c}), \S 813(\mathrm{c}$ ) (1994)).

16. See Pub. L. $100-430, \S 8(2), 102$ Stat. 1619, 1628 (1988) (codified as amended at 42 U.S.C. $\S$ $3610(\mathrm{~g})(2)(\mathrm{A})(1994))$ (inserting section $810(\mathrm{~g})(2)(\mathrm{A}))$.

17. See infra note 47. No one, however, suggested that the regime of mandatory enforcement by the Department of Justice, which occurs once a reasonable cause determination has been made by another federal agency, should be imported into ADA Title III from the Fair Housing Amendments Act of 1988.

18. Nonetheless, because of the availability of civil damages in an action brought under ADA Title III by the Attorney General, ADA Title III has a somewhat broader relief provision than CRA Title II. CRA Title Il has never been amended to provide for civil damages when the Attomey General brings suit.

19. Although this article focuses on the hypothesis that few lawsuits have been filed under the ADA because of the problems with its relief provisions, this is not the only explanation for the pattern. Another plausible explanation is that it is difficult to file class action remedies under the Title. Class actions historically have been the vehicle used to secure compliance with CRA Title II since a policy of racial exclusion would affect an entire class of AfricanAmericans. In contrast, the community of individuals with disabilities is quite diverse. Not all members of the disability community are affected by an exclusionary practice. For example, the first major ADA Title III case involved the refusal of a dentist to treat individuals with HIV in his office if they needed certain dental treatment, in that case, having a cavity filled. See Bragdon v. Abbott, 524 U.S. 624 (1998). One plaintiff challenged Dr. Bragdon's practice. Indeed, it would have been impossible to find a class of similarly situated individuals in that geographical area who could have been members of a proper class. See Fed. R. Civ. Proc. 23(a) (delineating class action requirements). 
plaintiffs' incentives to bring a lawsuit under ADA Title III. Although state law can sometimes serve as a remedial gap filler in such situations, that result has not occurred under ADA Title III. Many states passed their own civil rights laws with broader remedial provisions subsequent to the passage of CRA Title $\mathrm{II}^{20}$, but few have used the passage of ADA Title III as impetus for expanding their state antidiscrimination remedies in the area of disability discrimination. As it has only been ten years since the passage of the ADA, additional state legislative action may be forthcoming, but there is little reason to believe that further "filling the gap" will occur under ADA Title III. State law remedies in this area are very limited and are sometimes contained in antiquated statutes in serious need of updating, yet little legislative activity is occurring in this area of the law on the state level. ${ }^{21}$

The lack of success under ADA Title III has been hidden by the seeming success of the plaintiff in Bragdon v. Abbott, the first major ADA Title III case. ${ }^{22}$ Sidney Abbott brought suit under ADA Title III when Dr. Randon Bragdon refused to fill her cavity in his office in September $1994 .^{23}$ Four and a half years later, the courts concluded that Abbott is an individual with a disability and that she is entitled to injunctive relief under ADA Title III. ${ }^{24}$

Sidney Abbott is one of only a few plaintiffs who have been able to obtain effective relief for a violation of ADA Title III. ${ }^{25}$ Her ability to obtain relief, however, can be better attributed to the fact that both of the parties to the case were ideologically committed to having a court resolve the matter, rather than to the design of the statute. Dr. Bragdon had made his views on not treating patients with HIV publicly known and apparently welcomed a legal challenge to his position. ${ }^{26}$ Abbott was a "test" plaintiff who visited Dr. Bragdon's office knowing that he would refuse to fill her cavity in his office. ${ }^{27}$ She needed no financial incentive to file suit and, in truth, could have readily obtained dental treatment elsewhere. ${ }^{28}$ She

20. Compare infra Tables I, at 407 , and Table II, at 409 (illustrating that only six states have amended their anti-discrimination statutes to include compensatory damages).

21. See infra Table I, at 407 (comparing characteristics of state public accommodation statutes prohibiting disability discrimination).

22. 524 U.S. at 624. Abbott was denied dental treatment at her dentist's office because of her HIV-positive status. She prevailed in the trial court on a motion for summary judgment on the issues of whether she was an individual with a disability (yes) and whether she posed a direct threat to the dentist (no). Abbott v. Bragdon, 912 F. Supp. 580 (D. Me. 1995). Her case was affirmed by the First Circuit, 107 F.3d 934 (1st Cir. 1997), and affirmed and remanded by the United States Supreme Court on the direct threat issue, 524 U.S. 624 (1998). On remand, the First Circuit again affirmed the grant of summary judgment, $163 \mathrm{~F} .3 \mathrm{~d} 87$ (1st Cir. 1998). Bragdon's request for certiorari to the United States Supreme Court was denied. Bragdon v. Abbott, 119 S. Ct. 1805 (1999).

23. 524 U.S. at 628 .

24. Dr. Bragdon is legally obligated to fill her cavity in his office, because his services are covered under ADA Title III and such dental treatment would not pose a significant risk to his health or safety, or that of others. See 163 F.3d 87, cent denied, 119 S. Cl. 1805 (1999).

25. See discussion accompanying infra Part II.

26. See John Ripley, Ruling Upheld on HIV Dental Patient Treatment, BANGOR DalLY NEwS, Apr. 13, 1996, available in LEXIS, NEWS Library, BGRDLY File.

27. Id.

28. Id. 
was entitled to $\$ 10,000$ in damages under Maine law, ${ }^{29}$ but decided not to pursue that relief because "the lawsuit was filed on principle." "30 Although Dr. Bragdon could have challenged her standing to bring suit on justiciability grounds, he never made that claim, most likely because he desired a decision on the merits. ${ }^{31}$ Both parties therefore actually sought-and received-a decision on the merits. Because the case was primarily one of principle, injunctive relief was presumably satisfactory to Abbott.

The little academic discussion ${ }^{32}$ that has occurred on ADA Title III has criticized the Justice Department for preferring education to litigation, and for not vigorously enforcing the Title. ${ }^{33}$ Although I agree that Title III poses enforcement problems, it is wrong to blame the Justice Department for these problems. Enforcement problems with Title III exist because of the limited relief available under the statute, coupled with courts' narrow interpretations of that relief provision. Rather than criticizing the Department of Justice for a lack of enforcement, a review of the settlements that Justice Department attorneys have entered suggests that the Department should be applauded for settlements that often go beyond the requirements of the statutory language.

In Part I of this article, I will discuss the relief available under ADA Title III, CRA Title II, and the FHA. In Part II, I will examine the existing evidence of the effectiveness of ADA Title III. I will examine judicial outcomes (Part A), verdict outcomes (Part B), and settlement outcomes (Part C). I will argue that this evidence indicates that Title III suffers from under-enforcement due to the limited range of remedies that courts have construed are available. In Part III, I will

29. See ME. REv. STAT. ANN. tit. $5, \& 4613(2)(B)(7)$ (West Supp. 1998) (providing for "civil penal damages [10 the victim of unlawful discrimination] not in excess of $\$ 10,000$ in the case of the first order under this Act against the respondent, not in excess of $\$ 25,000$ in the case of a $2^{\text {nd }}$ order against the respondent arising under the same subchapter of this Act and not in excess of $\$ 50,000$ in the case of a 3rd or subsequent order against the respondent arising under the same subchapter of this Act, except that the total amount of civil penal damages awarded in any action filed under this Act may not exceed the limits contained in this subparagraph.").

30. See Ripley, supra note 26.

31. A court, of course, could have raised the jurisdiction issue sua sponte but none of the courts of record raised the issue.

32. The only significant discussion of ADA Title III was written by Professor Robert L. Burgdorf, Jr. who, himself, was a leading advocate for the passage of the ADA. See Roben L. Burgdorf Jr., "Equal Members of the Community": The Public Accommodations Provisions of the Americans with Disabilities Act, 64 TEMP. L. Rev. 551 (1991). This article does an excellent job of describing the requirements of ADA Title III. However, because it was written before the ADA became effective, it has little discussion of its legislative history or subsequent case development.

33. See Paul V. Sullivan, Note, The Americans with Disabilities Act of 1990: An Analysis of Title III and Applicable Case Law, 29 SUFFOLK U. L. REv. 1117, $1141-42$ (1995). Sullivan's article notes that:

Settlement agreements with the Department of Justice have resulted in many of the accomplishments of Title III. Commentators reason that initial litigation has been sparse because the government has placed a greater emphasis on education. Commentators, however, have noted that litigation should increase as the Department of Justice shifts from ADA education to ADA enforcement. Currently, many disability advocates are dismayed because some entities are not voluntarily complying with Title III, and compliance comes only after threats of litigation or actual litigation. In addition, the disabled and their advocates are concerned that political eagerness to shrink government might undermine the effectiveness of the ADA. 
discuss the limited remedies currently available under state law to show that state law is not currently "filling the gaps" in remedies under ADA Title III, as has historically occurred under CRA Title II. In Part IV, I will conclude that the current trend of under-enforcement of ADA Title III should cause us to consider enhancing remedies at the state and federal level.

I.

\section{LEGISLATIVE HISTORY}

\section{A. The First Bill}

The Americans with Disabilities Act was first introduced as H.R. $4498^{34}$ by Representative Coelho and as $S .2345^{35}$ by Senator Weicker in 1988. These bills were the outgrowth of the work on the National Council on the Handicapped, an independent federal agency whose 15 members were appointed by President Reagan and confirmed by the Senate. ${ }^{36}$

These two initial bills contained much broader anti-discrimination coverage than the bill that eventually was enacted as the Americans with Disabilities Act. ${ }^{37}$ The original bill was not divided into titles like the final bill. Instead, it had sections banning different types of discriminatory activities. Section 4 prohibited discrimination in employment. Section 5 prohibited discrimination in access to services or programs; prohibited architectural and other barriers; and made it unlawful to: (1) refuse to grant reasonable accommodations, (2) impose disqualifying selection criteria, and (3) engage in associational discrimination because of someone's relationship to an individual with a disability. ${ }^{38}$

The original bill contained much stronger language than the ultimately enacted ADA.

34. The bill was referred jointly to the Committees on Education and Labor, the Judiciary, Energy and Commerce, and Public Works and Transportation Committees. See H.R. 4498, 100th Cong. (1988).

35. See 134 CONG. REC. 9357 (1988).

36. See id. (statement of Senator Weicker in introducing S. 2345); see also 134 CONG. REC. 9382 (1988) (statement of Senator Harkin as chairman of the Subcommittee on the Handicapped).

37. Most notably, the definition of "disability" (which was then termed "on the basis of handicap") was much broader. In the initial bills, an individual had only to demonstrate that he or she was treated differently "because of a physical or mental impairment, perceived impaiment, or record of impairment." H.R. 4498, § 3(1). The term "physical or mental impairment" was also much broader, only requiring proof of a "physiological disorder or condition, cosmetic disfigurement, or anatomical loss affecting one or more systems of the body" or "any mental or psychological disorder, such as mental retardation, organic brain syndrome, emotional or mental illness, and specific learning disabilities." Id. at § 3(2).

38. Each of these sections was stronger than the ultimately enacted bill. By way of example, the reasonable accommodation section made no reference to the defense of undue hardship. The section most unlike the finally enacted bill was the barriers section, which provided that:

It shall be discriminatory (A) to establish or impose; or (B) to fail or refuse to remove; any architectural, transportation, or communication barriers that prevent the access or limit the participation of persons on the basis of handicap.

H.R. 4498, §5(a)(2).

39. The barriers section makes no distinction between new, altered or existing structures. It also specifically 
Most importantly, for the purposes of the present discussion, the enforcement section of the original bill was much stronger than the enforcement provision in the finally enacted ADA. The original bill provided that:

Any person who believes that he or she or any specific class of individuals is being or is about to be subjected to discrimination on the basis of handicap in violation of this Act, shall have a right, by himself or herself, or by a representative, to file a civil action for injunctive relief, monetary damages, or both in a district court of the United States. ${ }^{40}$

The exhaustion of administrative enforcement procedures was only required for actions involving employment discrimination. Claims of discrimination involving barriers to access at public accommodations could be brought by private citizens for monetary damages. In contrast, the bill that was finally enacted permitted private parties to obtain only injunctive relief ${ }^{41}$-a weaker remedy.

\section{B. Weakening of Legislation}

Even on the day when the ADA was first introduced, Senator Dole, a key sponsor of the ADA, spoke in favor of the need for such a bill but also stated that compromises were needed that would weaken the bill:

mentions transportation barriers that were not listed in the finally enacted ADA. The defenses that are provided for this section are minimal. Section $7(a)(1)$ states:

The failure or refusal to remove architectural, transportation and communication barriers, and to make reasonable accommodations required under section 5(a) shall not constitute an unlawful act of discrimination on the basis of handicap if such barrier removal or accommodation would fundamentally alter the essential nature, or threaten the existence of, the program, activity, business, or facility in question.

H.R. 4498, \& 7(a)(1).

This early version of the ADA also included considerably stronger language with respect to the removal of communication barriers than the final bill. Section $8(\mathrm{~h})(3)$ stated that:

Under appropriate circumstances, the prohibition or removal of communication barriers or making a reasonable accommodation may require:

(A) the provision and maintenance of devices such as Telecommunications Devices for the Deaf, visual aids such as flashing alarms and indicators, decoders, and augmentative communication devices for nonvocal persons such as language, symbol or alphabet boards;

(B) the provision of such services as interpreting, reading, audio or video taping, and notetaking, by qualified personnel;

(C) the development and effective operation of such systems as captioning, assistive listening systems, including audio induction loops, and infrared, FM or AM communications, and telephone relay services system;

(D) the development and effective use of alternative signage and information media, such as brailled or audio information, and visual alerts for audio announcements and other information; and

(E) the modification of devices, services, systems, and signage and information media, such as audio input/output on a computer terminal, adapted software, flashing lights as an attachment to a telephone, and amplifiers on telephone handsets.

H.R. $4498 \S 8(\mathrm{~h})(3)$. Ultimately, the only of these requirements to survive passage were the telephone relay services requirements.

Whereas the version of the statute that was enacted only requires the removal of barriers for existing entities meeting the narrow definition of public accommodation, the original bill covered all commercial entities. Senator Weicker explained that "simple justice argues strongly for requiring the removal of barriers that exclude or limit the participation of people with disabilities." 134 CONG. REC. 9378 (1988)

40. H.R. 4498, 100th Cong. $\$ 9$ (b) (1988).

41. 42 U.S.C. $\$ 12188(\mathrm{a})(2)$ (1994). 
I have reservations about many aspects of this bill including the elimination of the undue hardship criteria for reasonable accommodation, clarification on what constitutes a public accommodation and what such public accommodations would be required to do under the retrofitting provisions of this bill, what do we mean by transportation services and what is the scope of the provisions of this bill to intrastate transportation systems. ${ }^{42}$

Subcommittees of the United States Senate held hearings nearly a year later on S. 933, a modified version of the ADA that was introduced in the next Congress by Senator Harkin. Senator Harkin, who was the key sponsor of the ADA in the Senate, did not immediately acquiesce to Senator Dole's views about the need to limit the provision on relief. Senate Bill 933, which Senator Harkin introduced in the Senate on May 9, 1989, provided that the enforcement scheme for the FHA (which included both compensatory and punitive damages) should be available to redress discrimination at places of public accommodation. ${ }^{43}$

Attorney General Thornburgh spoke in favor of the new bill, but made it clear that ADA Title III needed serious revision to limit its scope and protection. His objections were three-fold: (1) businesses could not make accurate predictions of the types of modifications required because the "readily achievable" compliance standard was not well defined and did not exist under Section 504 of the Rehabilitation Act, (2) the remedies for violations of ADA Title III should parallel the pre-existing remedies already present under CRA Title II, rather than the broader remedies existing in the FHA, and (3) the scope of businesses covered by ADA Title III should be narrowed so as not to impose undue hardship on small businesses. ${ }^{44}$ Most of these suggested amendments were adopted before enactment of the final bill. The term "readily achievable" was retained but it was defined as meaning "easily accomplishable and able to be carried out without much difficulty or expense." ${ }^{45}$ Explicit factors, such as the size and financial resources of the covered entity were added as factors to be considered when determining whether an accommodation was readily achievable, to make clear that the burden on small businesses would be minimal. ${ }^{46}$

Despite his recognition of the need for strong remedies, Senator Harkin capitulated on the remedies issue five months later, making it clear that this compromise was necessary to attain a bipartisan bill with a broad scope of coverage:

Senator Kennedy and I are committed to this compromise. We will oppose all weakening amendments. We will also oppose any amendments that are intended to strengthen the substitute, if these amendments do not have the support of the

42. 134 CONG. REC. 9386 (1988).

43. S. 933, 101st Cong. $\$ 405$ (1989) (incorporating Fair Housing Act remedies with "reference to a practice that is discriminatory under this title concerning a public accommodation or public transportation service operated by a private entity.").

44. See generally Hearings Before the Committee on Labor and Human Resources and the Subcommittee of the Handicapped on S. 933, 101st Cong. (May 9, 10, 16, and June 22, 1989) [hereinafter Hearings].

45. 42 U.S.C. $\$ 12181(9)$ (1994).

46. See id. § 12181(9)(A)-(D). 
administration and Senator Dole. We are pleased that the administration and Senator Dole share this commitment. We hope that other Senators will understand how fragile this compromise is and will support it.

The major component of the compromise was the agreement by the chief Senate sponsors to cutback the remedies included in the original bill in exchange for a broad scope of coverage under the public accommodations title of the bill; in other words to extend protections to most commercial establishments large and small open to the public. We would thus consider any amendment that pertains to either of these two aspects of the legislation an amendment designed to destroy this fragile compromise. $^{47}$

In the name of a "fragile compromise," the remedies underlying ADA Title III were limited in exchange for an expansive list of commercial entities covered by the statute. The compromises accepted during passage of the ADA are not unusual. Enforcement was traded for scope of coverage. The participants in this compromise recognized, however, that the ADA would need to be re-evaluated over time to see if it was effective. Attorney General Thornburgh recommended a "cautious" approach with continuing discussion and dialogue over time to see if a purely injunctive strategy would work. ${ }^{48}$

Thus, the scope of coverage and strength of enforcement of ADA Title III were limited during the legislative process. The argument advanced for weakening the remedial scheme was that injunctive relief had proven effective under CRA Title II. Therefore, there was no need for other relief, such as monetary relief. Nonetheless, proponents of the ADA were concerned whether injunctive relief would be effective. This article next examines the effectiveness of the ADA Title III remedies in light of our first decade of enforcement experience.

\section{Limitations of Civil Rights Act Analogies}

A fuller understanding of our experience under the civil rights laws should cause us to question the assumption that injunctive relief serves the objectives of ADA Title III. The scope of CRA Title II is narrower than the scope of ADA Title III. In addition, there is a broader array of state law remedies to supplement CRA Title II remedies than there are state law remedies to supplement ADA Title III remedies. Even assuming the effectiveness of the remedial scheme of CRA Title II, there are many reasons to doubt that a similar remedial scheme would be effective under ADA Title III.

A better analogy for ADA Title III is found by looking at the FHA. With the passage of time, Congress concluded that broad compensatory and punitive damages are required to provide effective remedies under the FHA (along with an ambitious government enforcement scheme). The limited remedies passed under CRA Title II were part of a fragile compromise in order to enhance passage of the statute in a bipartisan atmosphere. To date, these remedies have not proven

47. 135 CONG. REC. 19,803 (1989) (emphasis added).

48. Hearings, supra note 44 , at 210 (testimony of Attorney General Thornburgh). 
effective under ADA Title III.

\section{Title II of the Civil Rights Act of 1964}

Although CRA Title VII has received the most legal attention in the past several decades, it was the need for CRA Title II that was most vividly in the public's imagination at the time the Civil Rights Act was passed. Four black students who were refused cups of coffee in a Woolworth's store in Greensboro, North Carolina on February 1, 1960, began a series of sit-ins and civil disobedience that formed the backdrop for the passage of the Civil Rights Act. ${ }^{49}$

Senator Weicker emphasized the analogy to those four black students in his opening remarks as sponsor of the ADA:

People with cerebral palsy are turned away from restaurants because proprietors say their appearance will upset other patrons. People who use wheelchairs are blocked by curbs, steps, and narrow doorways from getting into many arenas, stadiums, theaters, and other public buildings. Many such facilities have done no planning for the use of their services by people with hearing or visual impairments.

It has been over 30 years since some zoos and parks were closed to keep blacks from visiting them during the peak of civil rights demonstrations and boycotts. Yet it was only last month that the Washington Post reported the story of a New Jersey zoo keeper who refused to admit children with downs syndrome because he feared they would upset the chimpanzees.

.... [P]eople with disabilities still have to chain themselves to buses and to block their movement in order to focus the attention of the transit industry and the general public on the fact that most buses are inaccessible to them. 'We aren't forced to the back of the bus,' they say, 'we can't get on the bus at all.

Senator Weicker could also have described the analogy to CRA Title II in another way-that ADA Title III, like its counterpart in the Civil Rights Act of 1964 , was watered down during the legislative process to enhance its potential for enactment.

In the original civil rights bill proposed to Congress by President John F. Kennedy, the scope of protection under CRA Title II was somewhat broader than what was ultimately enacted. The original bill prohibited discrimination in public accommodations, including all places of lodging, eating, and amusement and other retail or service establishments. ${ }^{51}$ That bill was modified many times before ultimate passage. Most importantly, as a result of the McCulloch-Justice Department compromise, ${ }^{52}$ it specifically exempted private clubs ${ }^{53}$ and failed to

49. For discussion of the impact of CRA Title II on ADA Title III, see Burgdorf, supra note 32, at 552-53.

50. 134 CONG. REC. 9376 (1988).

51. See Charles \& Barbara Whalen, The longest Debate: A Legislative HiStory of THE 1964 CIVIL RIGHTS ACT 1 (1985).

52. William McCulloch (R-Ohio) was the ranking Republican member of the subcommittee of the House Judiciary Committee when the Civil Rights Act was introduced in the House in 1963 . He agreed to provide seven Republican votes for support of the Civil Rights Act in exchange for various compromises that weakened the bill, but 
explicitly cover: "any retail shop, department store, market, drugstore, gasoline station, or other public places which keep goods for sale." ${ }^{54}$ Like ADA Title III, the final CRA Title II listed specific entities that are covered such as hotels, restaurants and places of entertainment, rather than including a more expansive generic definition of places open to the public. Although the rationale for limiting CRA Title II to those entities was never fully explained in the legislative history, one comment by Representative "Judge" Smith may have captured some of the sentiment at the time. Referring to the fact that a chiropodist whose office was in a hotel would be covered by CRA Title II, he is reported to have made a "shrill outburst": "If I were cutting corns ... I would want to know whose feet I would have to be monkeying around with. I would want to know whether they smelled good or bad." 55

Civil rights proponents, by contrast, saw no reason to exempt retail or service establishments from CRA Title II. For example, Representative Robert W. Kastenmeier criticized the limited scope of CRA Title II in his additional views that he filed as part of the House Judiciary Committee Report. Kastenmeier compared the strength of the original bill to the final bill. With respect to CRA Title II, he noted:

[T] he bill would allow discrimination to continue in barber shops, beauty parlors, many other service establishments, retail stores, bowling alleys, and other places of recreation and participation sports, unless such places serve food. It is hard to follow a morality which allows one bowling alley to remain segregated, while another bowling alley down the street which serves sandwiches must allow Negroes to bowl. There may be constitutional limitations on what activities can be covered by Federal legislation, but the categories covered by title II of the reported bill are not based on constitutional limitations. ${ }^{56}$

Similarly, in one of the few constitutional cases to discuss the right of a property owner to have the state enforce his desire to exclude blacks from a restaurant, Justice Douglas in a stinging concurrence argued in Bell v. Maryland ${ }^{57}$ that the Constitution permits no discrimination of this sort in any place of public accommodation:

Here [this case] it is a restaurant refusing service to a Negro. But so far as principle and law are concerned it might just as well be a hospital refusing admission to a sick or injured Negro ... or a drugstore refusing antibiotics to a Negro, or a bus denying

also enhanced its likelihood of ultimate passage. See id. at 10-14, 59-64.

53. See id. at 239.

54. Staff of THE House of RePresentatives COMM. ON THE Judiclary, 88th CONG., H.R. 7152 , at 43 (Comm. Print No. 2, 1963) (compare previous language on page 14 with new language on page 43 of Committee Print of bill).

55. WHALEN, supra note 51, at 110. Later, Smith supposedly removed the sentences from the official transcript of the proceedings in the Congressional Record. See id.

56. Additional Majority Views of Hon. Robert W. Kastenmeier, House Judiciary Committee Report No. 88-914 (1963), reprinted in UNITED STATES EQUAL EMPLOYMENT OPPORTUNITY COMMISSION, LEGISLATIVE HISTORY OF TITLES VII AND XI OF CIVIL RIGHTS ACT OF 1964, at 2040-41 (1968).

57. 378 U.S. 226 (1964). 
transportation to a Negro, or a telephone company refusing to install a telephone in a Negro's home .... Constitutionally speaking, why should Hooper Food Co., Inc., or Peoples Drug Stores-or any other establishment that dispenses food or medicines--stand on a higher, more sanctified level than Greyhound Bus when it comes to a constitutional right to pick and choose its customers?

Ironically, the day that Justice Douglas issued the concurring opinion in Bell v. Maryland was also the day that the Civil Rights Act of 1964 returned to the Senate for deliberation. By then, it was far too late to consider any amendments to expand the Act's coverage to encompass the reach of what Justice Douglas considered constitutional. The bill was only able to become law two weeks later as a result of extraordinary political maneuvering. ${ }^{59}$ Political rather than constitutional concerns resulted in the limited scope of CRA Title II. Without the McCullochJustice Department compromise, the Civil Rights Act of 1964 would never have become law.

Not only did CRA Title II, as enacted in 1964, not cover retail and personal service establishments, but the Act has never been amended to provide broader protection. Although state law prohibits discrimination in retail stores in most states, seven states (Alabama, Florida, Georgia, Mississippi, North Carolina, South Carolina, and Texas) have no such statute. ${ }^{60}$

Another issue that had to be confronted when the CRA was considered was the question of what kinds of remedies should be enacted. Civil rights activists had examined possible enforcement schemes. In a book published in 1959, civil rights activist Jack Greenberg observed that three enforcement schemes are generally possible: "criminal prosecution, private civil suit for damages or injunction by an aggrieved person, and administrative or injunctive implementation by public officials." ${ }^{61}$ He considered criminal enforcement to be problematic because of the high burden of proof, and the fact that "[t]rial has to be by jury, which may very likely be as prejudiced as the defendant." ${ }^{, 62}$ Similarly, he argued, civil suits for damages are problematic because they also involve juries, as well as the costs of engaging counsel. ${ }^{63}$ His preferred mechanism was use of an administrative agency or attorney general that would vigorously enforce anti-discrimination laws at public expense and without jury trials. ${ }^{64}$ Other commentators argued that the token amounts that are awarded in actions for civil damages may not act as an effective deterrent; ${ }^{65}$ whereas, injunctive relief might be effective insofar as it would have a continuing effect, thereby permitting punishment for contempt if the injunctive

58. Id. at 252-53, 254-55.

59. See generally WHALEN, supra note 51, at 218-29.

60. See Joseph William Singer, No Right to Exclude: Public Accommodations and Private Property, 90 Nw. U. L. REV. 1283, 1290 (1996).

61. JACK GREenBERG, RACE RELATIONS AND AMERICAN LAW 15 (1959).

62. Id.

63. Id. at 16 .

64. "Here, injunctive suits or administrative implementation by the federal government would seem to be the most efficient way to proceed...."Id. at 17.

65. See Arthur Earl Bonfield, State Civil Rights Statutes: Some Proposals, 49 IowA L. REv. 1067, 1114 (1964). 
order was violated. ${ }^{66}$ Based on the experience with states that used criminal penalties and private civil actions for damages, some commentators argued "that neither criminal prosecutions nor private civil actions for damages appreciably decrease the incidence of discrimination or give its victims an adequate legal remedy." ${ }^{67}$ They emphasized the importance of injunctive relief with possible enforcement by an administrative agency, ${ }^{68}$ although some commentators suggested that there could be an option for a private civil action for damages. ${ }^{69}$

The Civil Rights Act generally reflected the approach recommended by Greenberg and other commentators, although each Title of the Civil Rights Act utilized somewhat different enforcement schemes. CRA Title VII (the employment discrimination title) created a private right of action for make-whole relief and a modest administrative enforcement mechanism. ${ }^{70}$ These remedies were enhanced in 1972 to create a stronger administrative enforcement structure, ${ }^{71}$ and in 1991 to create the possibility of compensatory or punitive damages. ${ }^{72}$ CRA Title II (the public accommodation title) created a private right of action for preventive or injunctive relief with the possibility of intervention by the Attorney General if a complaining party could certify to the court that the case was of general public importance. ${ }^{73}$ However, even when the Attorney General intervened, CRA Title II did not provide for any kind of monetary damages. ${ }^{74}$ Moreover, unlike CRA Title VII, the remedies have not been enhanced since 1964. And unlike the FHA, the intervention on the part of the Attorney General is entirely discretionary.

Nevertheless, CRA Title II has proven to be a relatively effective tool in eliminating discrimination in places of public accommodation. Its effect has been two-fold. First, the availability of structural injunctions has led to large-scale changes in the way public accommodations conduct business. ${ }^{75}$ Second, state law has filled the remedial gap by providing compensatory damages and more

66. See Dennis L. Wright, Note, State Legislative Response to the Federal Civil Rights Act: A Proposal, 9 UTAH L. REV. 434, 449 (1964-1965).

67. See Bonfield, supra note 65 , at 1114 .

68. See Wright, supra note 66 , at 449.

69. See Bonfield, supra note 65 , at 1119.

70. See Civil Rights Act of 1964, Pub. L. No. 88-352, § 706, July 2, 1964, 78 Stat. 241, 259 (1964) (codified as amended at 42 U.S.C. § 2000e-5 (Supp. 1964-1969)) (amended 1972).

71. The administrative enforcement mechanism under Title VII was enhanced considerably in 1972 when the Equal Employment Opportunity Commission was given the power to bring a civil action against any respondent not a government, governmental agency, or political subdivision where the Commission has determined that there is reasonable cause to believe that the charge is true. When the respondent is a govermmental entity, the Commission is required to refer the charge to the Attomey General who may bring a civil action against the respondent in a federal court. See Equal Employment Opportunity Act of 1972, Pub. L. No. 92-261, sec. 4(a), § 706, 86 Stat. 103, 104-05 (1972) (codified as amended at 42 U.S.C. § 2000e-5 (1988)) (amended 1991).

72. The private cause of action was enhanced in 1991 when compensatory and punitive damages became available. See Civil Rights Act of 1991, Pub. L. No. 102-166, sec. 102, § 1977A(b), 105 Stat. 1071, 1073 (codified at 42 U.S.C. $\S 1981 \mathrm{a}(\mathrm{b})(1994))$.

73. See 42 U.S.C. § 2000a-3(a) (1994).

74. See id. $\S 2000 \mathrm{a}-3(\mathrm{~b})$.

75. See infra Part 1. D., at 393. 
expansive statutory coverage than CRA Title II. ${ }^{76}$ Thus, an ability to effectively enforce an anti-discrimination principle in the area of public accommodations may be attributable to the partnership of state anti-discrimination laws and CRA Title II rather than attributable to CRA Title II alone.

The effectiveness of banning race discrimination at places of public accommodation may have also occurred through another important statutory vehicle-section 1981. ${ }^{77}$ Several courts have concluded that private plaintiffs can sue for infringement of contract under section 1981 to obtain monetary damages when they are denied access to, or discriminated against, by public accommodations. $^{78}$ That cause of action is not available in the disability area, however, because section 1981 only applies to race discrimination. ${ }^{79}$

In assessing the performance of ADA Title III, one needs to ask whether structural injunctions and supplemental state or federal law remedies are likely in this area. Given the narrow way that many courts have interpreted their remedial powers under ADA Title III, structural injunctions appear unlikely. Moreover, the ten year record of limited state law amendments suggests that enhanced relief at the state law level is unlikely. It may be that an amendment to the ADA is the only possible way to improve the enforcement of ADA Title III, since section 1981 is not available to enhance the penalties in the disability area.

\section{Fair Housing Act Amendments of 1988}

Another analogy was also available when ADA Title III was being debatedthe Fair Housing Act (FHA). As enacted in 1968, the FHA provided that plaintiffs could recover "actual damages and not more than $\$ 1,000$ punitive damages, together with court costs and reasonable attorney fees in the case of a prevailing plaintiff ${ }^{, 80}$ to remedy race discrimination in the rental or sale of housing. The Act

76. See infra Table II, at 408 .

77. Civil Rights Act of 1866 (codified as amended at 42 U.S.C. $§ 1981$ (1994)).

78. See, e.g., Perry v. Command Performance, 913 F.2d 99, 100 (3rd Cir. 1990) (section 1981 action based on a beauty salon's refusal to provide services to an African-American woman); Watson v. Fraternal Order of Eagles, 915 F.2d 235, 240 (6th Cir. 1990) (allegations of refusal to sell soft drinks to guests at club violated section 1981); McCaleb v. Pizza Hut of America, Inc., 28 F. Supp.2d 1043, 1047 (N.D. Ill. 1998) (cause of action under section 1981 for failing to provide plaintiffs with range of services while eating their meals); Harrison v. Denny's Restaurant, No. C-96-0343 (PJH), 1997 WL 227963 (N.D. Cal., Apr. 24, 1997) (denial of service at restaurant can violate section 1981 although mere slow service does not violate section 1981); Рerry v. Burger King Corp., 924 F. Supp. 548, 552 (S.D.N.Y. 1996) (refusal to allow plaintiff to use bathroom was sufficient to state a cause of action under section 1981); Franceschi v. Hyatt Corp., 782 F. Supp. 712, 718 (D.P.R. 1992) (denial of access to hotel can state a cause of action under section 1981).

79. Section 1981 , by its wording, limits itself to issues of race discrimination:

All persons within the jurisdiction of the United States shall have the same right in every State and Territory to make and enforce contracts, to sue, be parties, give evidence, and to the full and equal benefit of all laws and proceedings for the security of persons and property as is enjoyed by white citizens, and shall be subject to like punishment, pains, penalties, taxes, licenses, and exactions of every kind, and to no other. 42 U.S.C. § 1981(a) (1994).

80. Fair Housing Act of 1968, Pub. L. No. 90-284, tit. VIII, $\S 812$ (c), 82 Stat. 73,88 (1968) (codified at 42 U.S.C. § 3612(c) (Supp. 1964-1969)) (amended 1988). 
was amended in 1988 to prohibit disability-based discrimination and to eliminate the cap on punitive damages. ${ }^{81}$ As noted in the House Judiciary Committee Report section by section analysis, the limitation on punitive damages was eliminated because the Committee concluded "that the limit on punitive damages served as a major impediment to imposing an effective deterrent on violators and a disincentive for private persons to bring suits under existing law." 82 Thus, although the FHA always contained a more ambitious range of remedies than ADA Title III, these remedies were broadened even further when disability discrimination in housing became unlawful.

During the debate over the ADA, Senator Harkin questioned why the FHA was not the appropriate analogy for ADA Title III rather than CRA Title II. ${ }^{83}$ The FHA contains important parallels to ADA Title III. Whereas the FHA covers the rental of apartments to individuals with disabilities, ADA Title III covers the rental of hotel rooms to people with disabilities. ${ }^{84}$ Yet, under current law, if a rental agent refuses to rent a house to an individual with a disability, he or she is subject to the full set of remedies provided under the FHA, while if a motel owner refuses to rent a motel room to that same individual, the individual would only be able to obtain injunctive relief.

It is arguable that housing discrimination has longer-term consequences for individual tenants than does discrimination at a place of temporary lodging, and thus stiffer penalties are appropriate for the former rather than the latter. But the lack of accessibility at places of public accommodation serves to impede the mobility of many individuals with disabilities. Given the nature of our highly mobile society, such impediments have daily effects on the basic requirements of living (e.g., grocery stores), and broader effects on the ability of an individual to work and travel (e.g., hotels and restaurants). Being confined to one's home due to the inaccessibility of the outside community can be as significant as having difficulty obtaining housing itself. Moreover, even if housing discrimination is somewhat more significant than discrimination at places of public accommodation, it is questionable whether the degree of difference is sufficiently significant to justify such widely divergent relief.

In deciding which analogy makes more sense-CRA Title II or the FHA-we must consider the change in social consensus since the passage of the Civil Rights Act in 1964. The Civil Rights Act was passed after what has been termed the "longest debate" due to a lengthy filibuster in the United States Senate. CRA Title II was also passed at a time when civil rights advocates had serious reservations about jury trials for victims of race discrimination. Those fears are largely unfounded today ${ }^{85}$ and, in any event, are not particularly relevant to the law of

81. 42 U.S.C. $\$ 3613$ (c) (1994). See supra note 15 (quoting text of section).

82. H.R. REP. No. 100-711, at 40 (1988), reprinted in 1988 U.S.C.C.A.N. 2173, 2201.

83. See supra note 47.

84. See 42 U.S.C. $\$ 12181$ (2)(A) (defining ADA Title III as only covering facilities for nonresidential use); see also supra note 12 (providing text of FHA).

85. When civil rights activists expressed concern about jury trials in the race area, they were assuming all-white 
disability discrimination. ${ }^{86}$ Jury trials are now commonplace under the Civil Rights Act of 1964 and state anti-discrimination laws.

By contrast, the Fair Housing Act Amendments of 1988 were passed by a bipartisan Congress. The remedies provided reflected the strong political and social commitment to making affordable housing available without discrimination on the basis of disability. The ADA was passed only two years later, again by a strongly bipartisan Congress. Although the scope of entities covered was narrowed during the legislative debate-as the scope was narrowed during the legislative debate of CRA Title II-the list of entities ultimately covered under the ADA was much more comprehensive than the list covered by CRA Title II. Our emerging social consensus about the inappropriateness of discrimination is strong enough to justify a more stringent set of remedies for both race and disability discrimination than in 1964.

Nonetheless, the proponents of the ADA were never able to move the discussion of remedies beyond that of injunctive relief. They were stuck with the limited remedies that had been negotiated at another time-1964 - and in another context-race discrimination-where the fear of jury trials was particularly strong. Senator Harkin understood the importance of ensuring that the Fair Housing Act remedies rather than the CRA Title II remedies would be available under the ADA. The bill introduced by Senator Harkin in the Senate Committee on Labor and Human Resources contained the FHA remedies for violations of the ADA's public accommodation section (what eventually was enacted as ADA Title III). ${ }^{87}$ At a Hearing held before the Committee on Labor and Human Resources and the Subcommittee of the Handicapped, Senator Harkin stated that "without the existence of damages as a remedy, you would not get widespread voluntary compliance or negotiated settlements, short of litigation.,"88

Attorney General Thornburgh, however, did not agree that the FHA remedies were appropriate under the FHA. In response to a question in which Senator Harkin asked Attorney General Thornburgh whether he thought the FHA remedies

juries. That assumption is no longer appropriate. See Batson v. Kentucky, 476 U.S. 79,83 (1986) (invalidating the use of race-based peremptory challenges).

86. My own research, in fact, suggests that victims of disability discrimination should be wary of bench trials because of the strong propensity of trial court judges to grant motions for summary judgment on behalf of defendants. See Ruth Colker, The Americans with Disabilities Act: A Windfall for Defendants, 34 HARV. C.R.-C.L. L. REV. 99, 101 (1999).

87. S. 933, as introduced in the Committee on Labor and Human Resources, stated:

Sec. 405. Enforcement.

Sections 802(i), 813, and 814(a) and (d) of the Fair Housing Act (42 U.S.C. 3602(i), 3613, and 3614(a) and

(d)) shall be available with respect to any aggrieved individual, except that -

(1) any reference to a discriminatory housing practice or breach of a conciliation agreement shall be

considered to be a reference to a practice that is discriminatory under this title concerning a public accommodation or public transportation service operated by a private entity; and (2) subparagraph (B) of paragraph (1) and paragraphs (2) and (3) of subsection (a) of section 813 shall not apply.

135 CONG. REC. 8512 (1989).

88. Hearings Before the Comm. on Labor and Human Resources and the Subcomm. of the Handicapped on S. 933, 101 st Cong. 209 (1989). 
should be available under ADA Title III, ${ }^{89}$ the Attorney General responded:

I think the view that the administration holds to is that this act should not be one designed to promote unnecessary litigation. The fair housing amendments of last year were adopted only after years of experience with the previous regimen of remedies, and I think that I can fairly express the view of the administration that those remedies are not necessarily appropriate for transport into a new piece of legislation without some similar experience in obtaining voluntary compliance and in securing the kinds of remedies that have been used in other civil rights areas, without particularly going to punitive damages and some of the more novel remedies proposed in this act, such as giving persons a right to enjoin action which is about to result in discrimination.

Again, before that kind of uncharted water is entered into in the remedial sense, some thought, I think, ought to be given to sticking with the remedial regimen that is contained in the present civil rights laws.

$\cdots$

We are a litigious society, Senator Harkin, whether we like it or not, and there are a lot of people out there that the first thing they want to do is sue somebody, and particularly when you have provided punitive damages, which we learned from recent experience can be somewhat limitless in their reach. We are merely making a plea for the tried and true remedies under Titles II and VII of the Civil Rights Act of 1964, which not only provide for more voluntary compliance but limit the amount of litigation that is necessarily going to ensue, and the prospect of having that litigation, in fact, prove an obstacle to achieving the goals that we seek. ${ }^{90}$

Attorney General Thornburgh's comments mischaracterized, in part, the experience under the FHA. Although the FHA's remedial scheme was strengthened in 1988, that remedial scheme has always been stronger than the one contained in the ADA. Since 1968, plaintiffs have been able to obtain actual damages and limited punitive damages under the FHA. The 1968 remedial scheme under the FHA would be far more effective under ADA Title III's purely injunctive scheme for relief.

Although Senator Harkin compromised in order to attain bipartisan support of the ADA, he forecast that the limited remedial scheme of ADA Title III would lead to few lawsuits and under-enforcement of the statute's mandate. Attorney General Thornburgh seemingly agreed that there might be few lawsuits but predicted that there would be sufficient voluntary compliance to enforce the statute's mandate. The experience under the FHA, however, was that even a remedial scheme providing actual damages and limited punitive damages was insufficient to enforce the mandate of the Act. Limited remedial schemes therefore need to be periodically revisited to see if they are effective. ${ }^{91}$

89. Id. at 209 .

90. Id. at 209-210.

91. While some might argue that the FHA is ineffective even with an enhanced remedial scheme, the merit of that argument is beyond the scope of this paper. 


\section{Effectiveness of Remedies}

Despite the limited scope of relief available under CRA Title II, there is far less discrimination on the basis of race at public accommodations today than there was in 1964. One no longer finds "Whites Only" signs on the doors of restaurants. The problems today are what we might call "second order" problems of discrimination-lesser service rather than a denial of entrance. Thus, in one of the most well-publicized public accommodation cases in recent years, a Denny's Restaurant in Maryland allegedly failed to serve six African-American Secret Service agents while the white agents were served second and third helpings. Two class action lawsuits were filed on behalf of 294,537 plaintiffs under federal and state law, with a reported settlement two years later of $\$ 46$ million and the discharge of more than 100 employees for discriminatory behavior. ${ }^{92}$ Denny's relatively prompt attempt to settle this lawsuit reflects the changing moral climate that has occurred since 1964. It is no longer good business, especially for a restaurant chain, to have the image of excluding African-American customers.

The second-order problems in the area of race discrimination are being redressed through a combination of state and federal law. Federal law gave the plaintiffs authority to seek a structural injunction against Denny's, while state law provided plaintiffs the opportunity to seek compensatory relief. The $\$ 46$ million price tag in the Denny's case was the result of broader protection available under state than federal anti-discrimination law. In addition, section 1981 can be used to enhance the penalty when individuals are denied service because of race. ${ }^{93}$

By contrast, the injunctive relief remedial scheme of ADA Title III has not been sufficiently effective in eliminating barriers to access for individuals with disabilities. Physical barriers such as steps-which preclude entrance by people who use wheelchairs-and the lack of Telecommunication Devices for the Deaf $(\mathrm{TDD})^{94}$ services at hotels-which impede the traveling opportunities of people who have hearing impairments-are only two commonplace examples of exclusion on the basis of disability by many places of public accommodation. Remedying violations of ADA Title III is different than remedying violations of CRA Title II. An apt analogy would be a case in which a restaurant refuses service because of the physical appearance of an individual with a disability. In the more typical case, however, the restaurant has effectively denied service by having a step at the front door. The step may have pre-dated passage of the ADA, and was probably not constructed with the intention of excluding a category of potential customers. In order to comply with the ADA, the restaurant must take the pro-active step of removing the barrier which, in turn, entails a cost for the restaurant. Under CRA

92. See Betsy Pisik, Denny's Mails Checks to Suit's Black Diners, WASH. TIMEs, Dec. 12, 1995 , at B10.

93. See supra note 78 .

94. A TDD is a telecommunication device attached to a telephone that permits individuals to communicate by typing their messages back and forth. Both parties must have a TDD for the system to operate properly. The instrument emits a signal to let a hearing listener know to switch his or her telephone to the TDD device. A TDD is a relatively inexpensive device (around \$200) yet most businesses do not own a TDD or, if they do own one, do not use it when telephoned by a person on a TDD. 
Title II, it arguably makes economic sense to ban discrimination, because a restaurant, for example, would ultimately incur more business if it began to serve African-Americans. ${ }^{95}$ That fact may also be true under ADA Title III. A restaurant that can serve customers who use wheelchairs will also attain increased business, not only from individuals with disabilities, but also from the friends and family of the individuals with disabilities. But the increased service will not result until after an initial expenditure of money on the part of the restaurant owner. The threat of injunctive relief is not sufficient to create compliance, because compliance requires a more proactive step than merely removing a "whites only" sign and may entail what is perceived to be a significant expense."

Further, injunctive relief has been ineffective under ADA Title III because of courts' narrow interpretations of their power to issue such relief. Courts have repeatedly concluded that they lacked jurisdiction to hear ADA Title III cases, because the plaintiffs' individual instances of discrimination did not create standing to seek injunctive relief. ${ }^{97}$ Many of the ADA Title III cases have involved a failure to provide medical services to individuals with disabilities, particularly individuals with HIV/AIDS. In such a situation, the plaintiff is likely to file suit against the doctor who provided treatment while also seeking treatment from another physician. Because the plaintiff obtained treatment from another physician, the courts reason that the case is moot since the injury is unlikely to recur and compensatory relief is not available. Thus, the courts have concluded that they are powerless to order any relief even though a flagrant violation of the ADA may have occurred. When a court can issue no relief, it often cannot maintain jurisdiction over the case; it must dismiss the case or, if there is a supplemental state action, remand the case to state court. ${ }^{98}$

The leading case governing this question of relief is City of Los Angeles v. Lyons. $^{99}$ Adolph Lyons brought a civil rights action against the city seeking damages, injunctive relief and declaratory relief stemming from an incident in

95. In the short term, some white customers might fail to patronize the restaurant. However, in the long term, the overall customer population would surely rise. Justice Douglas made this assertion through anecdotal data. See Bell v. Maryland, 378 U.S. 226, 265 n.2 (1964)

96. Even if the expense is fairly minimal, no entity may be pro-actively taking responsibility for the barrier removal. For example, in a landlord-tenant situation, neither entity may consider himself or herself to be responsible for the design or construction of the entrance. Inertia may therefore act as a deterrent to action.

97. See, e.g., Jairath v. Dyer, 154 F.3d 1280 (11th Cir. 1998) (filed suit under ADA Title III and state law after doctor refused to perform a Gore-Tex implant procedure on plaintiff; district court granted defendant's motion for summary judgment and refused to remand state law claim to state court; court of appeals reversed and remanded case with instruction to remand it to state court for consideration of the state law issue); see also Delil v. El Torito Restaurants, No. C 94-3900-CAL., 1997 WL 714866 (N.D. Cal. 1997) (no standing to sue for injunctive relief because there is no "'real and imminent threat' of future injury"); Hoepfl v. Barlow, 906 F. Supp. 317 (E.D. Va. 1995) (no standing to sue for injunctive relief under ADA, absent showing that realistic possibility existed that defendant's future discriminatory conduct would cause harm to plaintiff); Atakpa v. Perimeter Ob-Gyn Assocs, 912 F. Supp. 1566 (N.D. Ga. 1994) (patient did not have standing to seek injunctive relief under the ADA because she failed to allege that she will ever seek services from defendants in the future).

98. See generally 28 U.S.C. $\$ 1367$ (c)(3) (1994) (governing supplementary jurisdiction of related state law claims).

99. 461 U.S. 95 (1983). 
which a police officer used a "choke hold," allegedly pursuant to city policy, upon stopping Lyons for a traffic violation. The Supreme Court concluded that Lyons did not have standing to challenge the allegedly illegal conduct due to the "speculative nature of his claim that he will again experience injury as the result of that practice even if continued." 100 The Supreme Court recognized that there is an exception to the mootness doctrine when a claim "is capable of repetition, yet evades review." ${ }^{101}$ However, because Lyons also had an action for monetary relief, the Court ruled that his case did not come under that doctrine. But even if Lyons had not had other remedies, the Court suggested that it would have been hesitant to apply the "capable-of-repetition" doctrine because that "doctrine applies only in exceptional situations, and generally only where the named plaintiff can make a reasonable showing that he will again be subjected to the alleged illegality."102 Lyons could not make such a demonstration. In so ruling, the Court cited DeFunis v. Odegaard, ${ }^{103}$ an educational, reverse discrimination case, in which the plaintiff was in his final quarter of his last year of law school when the case reached the Supreme Court. Although the fact pattern may have been typical of other such cases, the Supreme Court declined to exercise jurisdiction, concluding that the issue raised by the plaintiff would likely be reviewable in the future. ${ }^{104}$ In two major civil rights cases involving injunctive relief-Lyons and DeFunis-the Supreme Court therefore declined to apply the "capable of repetition" doctrine to maintain jurisdiction over the plaintiff's request for injunctive relief.

The standards for the capable of repetition doctrine are stringent, ${ }^{105}$ but, in some cases, the Supreme Court has diluted the requirement that an individual must be likely to be affected by a future recurrence of a mooted dispute. The most well known example is Roe $v$. Wade. ${ }^{106}$ Observing that the normal gestational period is 266 days, the Court concluded that the case presented "a classic justification for a conclusion of nonmootness," 107 as a dispute capable of repetition, yet evading review. The Court made no specific finding that the plaintiff was likely to face another unwanted pregnancy while residing in the state of Texas. Similarly, the

100. Id. at 109.

101. Id.

102. Id.

103. 416 U.S. 312,319 (1974).

104. Id. And the Supreme Coun was correct. The issue was ultimately resolved in Regents of the Univ. of Calif. v. Bakke, 438 U.S. 265 (1978).

105. See generally United States v. W.T. Grant Co., 345 U.S. 629, 633 (1953) ("The necessary determination is that there exists some cognizable danger of recurrent violation, something more than the mere possibility which serves to keep the case alive.").

106. 410 U.S. 113 (1973)

107. Id. at 125 ("But when, as here, pregnancy is a significant fact in the litigation, the normal 266-day human gestation period is so short that the pregnancy will come to term before the usual appellate process is complete. If that termination makes a case moot, pregnancy litigation seldom will survive much beyond the trial stage, and appellate review will be effectively denied. Our law should not be that rigid. Pregnancy often comes more than once to the same woman, and in the general population, if man is to survive, it will always be with us. Pregnancy provides a classic justification for a conclusion of nonmootness. It truly could be 'capable of repetition, yet evading review.' ... We, therefore, agree with the District Court that Jane Roe had standing to undertake this litigation, that she presented a justiciable controversy, and that the termination of her 1970 pregnancy has not rendered her case moot."). 
Supreme Court has been seemingly liberal in accepting jurisdiction in a series of voting cases without any individualized showing that the problem is likely to recur in the future. John Anderson, for example, was permitted to challenge a time-offiling requirement that would have kept him off the 1980 presidential election ballot in Ohio. The Supreme Court heard the case, although the election was over by this time, and never asked whether Mr. Anderson was likely to seek the presidency again. ${ }^{108}$ Thus, while the Supreme Court refused to acknowledge a public policy exception to the mootness doctrine in DeFunis v. Odegaard, ${ }^{109}$ the abortion and election law decisions suggest that the Court is sometimes willing to dilute the mootness requirements when a public policy issue is likely to evade review. ${ }^{110}$

Courts that have applied Lyons to ADA Title III cases have applied the doctrine too stringently and have arguably misconstrued the nature of these Title III actions." ADA Title III cases do not involve extreme situations in which only a plaintiff's criminal conduct could cause future discrimination to occur. Instead, these are cases in which plaintiffs represent a class of litigants who repeatedly face instances of discrimination as a result of their own voluntary and lawful conduct. In Honig v. Doe, ${ }^{112}$ the Supreme Court distinguished between a situation in which an individual with a disability is likely to face future unlawful actions due to his disability and the Lyons situation where standing would require an expectation of repeated police misconduct. The Court said:

Our cases reveal that, for purposes of assessing the likelihood that state authorities will reinflict a given injury, we generally have been unwilling to assume that the party seeking relief will repeat the type of misconduct that would once again place him or her at risk of that injury ... No such reluctance, however, is warranted here.

108. See Anderson v. Celebrezze, 460 U.S. 780, 784 n. 3 (1983) ("Even though the 1980 election is over, the case is not moot."); see also Rosario v. Rockefeller, 410 U.S. 752, 756 n.5 (1973) ("Although the June primary election has been completed and the petitioners will be eligible to vote in the next scheduled New York primary, this case is not moot, since the question the petitioners raise is 'capable of repetition, yet evading review.'"); Bellotti v. Baird, 428 U.S. 132, $137 \mathrm{n} .7$ (1976) ("We note that the fact the pregnancy of Mary Moe I has been terminated ... in no way moots the case."); Doe v. Charleston Area Medical Ctr., 529 F.2d 638, 644 (4th Cir. 1975) ("Roe v. Wade ... clearly establishes that a woman retains standing and the case is not rendered moot by an abortion subsequent to the initiation of the action but before appellate review ... As the Supreme Court noted, this is the classical case of an action 'capable of repetition, yet evading review."); Fitzgerald v. Porter Mem'l Hosp., 523 F.2d 716, 717 n. 3 (7th Cir. 1975) ("Although all the plaintiffs have had their children, the case is not moot.").

109. 416 U.S. 312,316 (1974) ("Although as a matter of Washington state law it appears that this case would be saved from mootness by 'the great public interest in the continuing issues raised by this appeal' ... the fact remains that under Art. III '(e)ven in cases arising in the state courts, the question of mootness is a federal one which a federal coun must resolve before it assumes jurisdiction.").

110. Admittedly, the Court has also rendered narrow decisions on justiciability grounds in recent years. See, e.g., Arizonans for Official English v. Arizona, 117 S.Ct. 1055 (1997) (dismissing case as moot where employee resigned after decision rendered in the district court but before appeals were exhausted); Steel Co. v. Citizens for a Better Env't, 118 S.Ct. 1003 (1998) (dismissing case on standing grounds because none of the relief sought by respondent would likely remedy its alleged injury in fact). In Steel Co., the Court, citing Lyons, emphasized the importance of the allegations of future injury being "particular and concrete" where petitioners seek standing on the basis of their entitlement to injunctive relief.

111. See supra note 97 (listing the cases).

112. 484 U.S. 305 (1988). 
It is respondent Smith's very inability to conform his conduct to socially acceptable norms that renders him "handicapped" within the meaning of the [Education for All Handicapped Children Act]. ${ }^{113}$

Although Bragdon and other ADA plaintiffs may not be at risk of physical harm as a result of defendants' conduct, they, like the plaintiff in Honig, have the ability to put themselves in the position of having to face unlawful conduct in the future. Sidney Abbott could seek medical services from Dr. Bragdon in the future. ${ }^{114}$ And it is unlikely that Dr. Bragdon's refusal to treat patients with HIV infection in his office would change absent a court-ordered injunction, especially since he had taken a strong public position concerning his right not to treat patients with HIV. The choice of service provider belongs to Abbott; and the right to choose is reinforced in the ADA. An injunction would maintain the right to lawful choice. To preserve that right, an injunction is absolutely essential as a remedy.

Although Abbott strategically stated that she would continue to use Dr. Bragdon for dental services if she prevailed in the litigation, it really makes no sense to conclude that Congress intended to require Abbott to claim that she would use Dr. Bragdon's medical services after he made his private prejudices knownand refused to serve her-in order to have standing to sue. Application of the capable of repetition doctrine permits clearly unlawful conduct to be remedied by enjoining such conduct for the benefit of Sidney Abbott and other individuals with a disability. In the context of personal services, it is unlikely that anyone would engage the services of a provider again after the provider had engaged in blatant discrimination, since other providers are usually available. In deciding to cover personal service enterprises, and only permitting injunctive relief, Congress must have intended effective relief to be available. By narrowly construing the capable of repetition doctrine, the courts have departed from Congress' intentions. None of the courts that considered the Bragdon litigation raised the justiciability issue although they could have raised the issue of their own accord. The Supreme Court's decision in Bragdon implicitly reflects its understanding that jurisdiction is appropriate in this category of cases, since the Court had the power to raise the jurisdictional issue itself.

There is a long tradition of the courts ordering "structural injunctions"injunctions that involve a court actively in the life of a public entity such as a segregated school. ${ }^{115}$ Federal courts have invoked this power to take control of prisons, mental institutions, and public housing, and even to raise local property taxes and impose contempt citations and daily fines for failure to comply with

113. Id. at 320 .

114. I understand that Abbott did state in an interrogatory that she had not had the cavity filled prior to filing suit and would use Dr. Bragdon to fill her cavity if she obtained injunctive relief.

115. See generally Owen Fiss, The Supreme Cour 1978 Term: Foreword: The Forms of Justice, 93 HARv. L. REV. 1, 2 (1979) ("The structural suit is one in which a judge, confronting a state bureaucracy over values of constitutional dimension, undertakes to restructure the organization to eliminate a threat to those values posed by the present institutional arrangements."). 
judicially-mandated spending increases. ${ }^{16}$ Although the courts' use of these broad powers is controversial in the area of constitutional litigation, it is far less controversial for Congress to explicitly enact legislation designed to avoid a constitutional problem at the outset. Professor John Yoo, for example, a critic of constitutional structural injunctions, has argued that "Congress can cure constitutional violations before they occur, or it can make constitutional litigation unnecessary by providing clearer, more precise standards and procedures."117 ADA Title III is an example of such clear and precise standards and procedures. If a court has the power to require affirmative action-which benefits individuals in the future who were not a party to the original litigation-it is hard to see how a court does not have the power to grant injunctive relief to a named plaintiff who theoretically could seek to use the service she was denied in the future. Congress clearly concluded that injunctive relief was necessary to remedy the evils that it made unlawful through the passage of ADA Title III. It is wrong to use Article III's standing requirements to undermine Congress' purpose in enacting the ADA.

This kind of problem rarely arose under CRA Title II, because plaintiffs in those cases were likely to want to return to the restaurant or hotel in question (or at least could claim they had an interest in returning). Since CRA Title II does not cover personal service situations, it does not cover Bragdon-like fact patterns. When enacting the ADA, Congress was repeatedly told that the remedies under ADA Title III were the same as the remedies under CRA Title II. No one focused on whether those remedies would be adequate in the different kinds of fact patterns that exist under ADA Title III as compared to CRA Title II.

In addition, it is important to remember the historical rationale for injunctive relief under CRA Title II--a concern about the possibility of prejudiced juries not awarding any relief at all. Although that concern may have been appropriate in the United States in 1964 with regard to race discrimination lawsuits, that concern has little or no applicability to disability discrimination lawsuits brought after 1990 . My own research under ADA Title I (the employment discrimination title) suggests that plaintiffs have so little chance of prevailing before judges at bench trials that it is hard to imagine that juries would present an even more unsympathetic forum. ${ }^{118}$ If compensatory damages were available, the rare plaintiff in an ADA action who feared a prejudiced jury would still have the option of seeking only injunctive relief and thereby avoiding a jury trial.

II.

\section{ADA TITLE III RESULTS}

The most significant impact of ADA Title III's limited scope of relief is probably the small number of cases that have been filed under that title. In a

116. See generally John Choon Yoo, Who Measures the Chancellor's Foot? The Inherent Remedial Authority of the Federal Courts, 84 CALIF. L. REv. 1121, 1121-22 (1996).

117. $I d$. at 1168-69.

118. See Colker, supra note 86. 
previous article, ${ }^{119}$ I concluded that the courts of appeals had issued decisions in 475 cases under ADA Title I (the employment title) from June 1992 to July $1998 .^{120}$ By contrast, I have only been able to locate 25 ADA Title III appellate decisions for the same time period. Only 5 percent of the reported appellate cases are therefore ADA Title III cases.

Twenty-five appellate decisions are too few to provide a clear sense of how effective ADA Title III has been in remedying discrimination problems. I therefore have tried to supplement these results with other kinds of results-verdicts and settlements. The verdict data is reported in Table B and discussed in Part B below. The settlement data is discussed in Part $\mathrm{C}$ below. The verdict and settlement data suggests that Title III may be effective, particularly when supplemental state actions are available. It also may be effective when the federal government brings suit and seeks broad relief. But the verdict and settlement data still reflects small sample sizes, suggesting that ADA Title III's effectiveness may be largely dependent on voluntary compliance rather than litigation. Attomey General Thornburgh may have been correct to suggest that incentives to pursue litigation would be diminished through a limited remedial scheme, but it is hard to imagine that voluntary enforcement is effective when private parties can calculate that it is highly unlikely that any enforcement action for noncompliance would be brought against them. Twenty-five appellate decisions is quite disproportionate to the 475 cases decided under ADA Title I. While 475 cases may be considered excessive, 25 would appear to be too minimal.

\section{A. Appellate Litigation Results}

I was only able to find 25 appellate decisions that were reported on Westlaw. Of those 25 decisions, defendants prevailed below through dismissal or summary judgment in 18 of 25 cases (72\%). After the appellate process was completed, defendants still prevailed in 18 of 25 cases (although the mix of cases changed through six reversals). Although this result is a pro-defendant outcome, it is less pro-defendant in its orientation than the comparable results I have found under ADA Title I. Under ADA Title I, defendants prevail in $94 \%$ of the cases from which appeals were taken (448 of 475 ). After the appeal process was completed, defendants continued to prevail in $82 \%$ of the cases from which appeals were taken (389 of 475). In the Title I area, the appeals courts appear to have played a modestly corrective role, lessening the defendant-win rate from $94 \%$ to $82 \%$. Apparently, plaintiffs have a somewhat easier time prevailing under ADA Title III than ADA Title I, but are not very inclined even to attempt litigation under ADA Title III. 


\section{B. Verdict Data}

The verdict data confirms that plaintiffs are unlikely to sue under ADA Title III. Verdicts are rarely reported in published decisions so they are not a part of the set of cases discussed above in Part A. Although not all verdicts are readily available, there are verdict services in various regions of the country that report verdict data. Westlaw and Lexis report the results from many of these services.

I used these verdict services to locate all ADA cases reported by September 28, 1998. I was able to locate 109 verdicts in ADA cases heard in either state or federal court. Of these 109 cases, there were only 16 ADA Title III cases (ADA Title III cases were therefore about $16 \%$ of all ADA verdicts). Seven of these cases were brought in federal court and 9 were brought in state court. Plaintiffs were successful in 4 of 7 federal court actions and 4 of 9 state court actions with an overall success rate of 8 of 16 . The success rates for Title I and III actions were comparable. Iri Title I actions, plaintiffs were successful in 27 of 51 actions and in Title III actions, plaintiffs were successful in 17 of 39 actions. These figures are consistent with what the judicial expectations model would suggest. Cases are most likely to go to trial when both parties estimate that they have about a fifty percent chance of prevailing. Very strong and very weak cases should settle since the losing party should calculate that it is not economical to take the case to trial.

It is interesting to note the discrepancy between cases that go to a jury trial and are not appealed, with cases decided by the judge or jury that are appealed. Jury trials rarely occurred in the cases in my appellate sample. Most of the cases ended at a pre-trial stage through the entry of summary judgment. In the cases that did not go to a jury, plaintiffs had a much lower chance of prevailing than in cases that did go to the jury. In a previous article, I have hypothesized in the Title I context that judges are misusing the summary judgment device to avoid having potentially meritorious cases go to the jury. ${ }^{121}$ These Title III statistics, although not as extreme as the Title I statistics, provide further confirmation for this hypothesis.

The Title III data also suggests that we need not be concerned about excessive jury awards if compensatory and punitive damages were available under ADA Title III. All of these ADA Title III cases also included a supplemental state law action in which compensatory or punitive damages were available, such as a negligence per se theory. The typical plaintiff suffered a serious injury as a result of faulty accessibility standards, and therefore was eligible for damages under a negligence per se theory for a violation of a substantive standard (ADA) that led to an injury. Such plaintiffs typically received an award for about $\$ 10,000$, although one plaintiff attained an award of $\$ 512,000$ against a physician and a hospital for the failure to admit him to the hospital in violation of the ADA, EMTALA, and state tort law. ${ }^{122}$ These awards reflected compensation for actual physical injury due to a

121. See id. at 126.

122. See Howe v. Hull, No. 3:92CV7658 (N.D. Ohio, June 14, 1994), available in LEXIS, VERDCT Library. 
failure to meet ADA Title III standards.

Very few of these cases involved what might be considered stigmatic harm due to a lack of accessibility. The only exception to this pattern was a case against Sunnyvale Town Center for failing to provide crosswalks and parking for individuals with disabilities at its mall. ${ }^{123}$ The jury awarded a verdict for the plaintiff of $\$ 74,097$ in economic damages and $\$ 160,000$ in noneconomic damages. The case was then settled for $\$ 145,000$, including costs. ${ }^{124}$

These verdicts suggest that where plaintiffs have only a stigmatic claim of injury due to lack of accessibility, but no physical injury, juries will tend to calculate their injury as relatively minor. If the ADA were amended to include a right to relief for compensatory damages, it is reasonable to conclude that this trend would continue. ${ }^{25}$

It is also important to recognize that the jury verdict cases almost always involve situations where the plaintiff suffered a physical injury as a result of the failure to comply with ADA standards. Few of these cases involved solely a lack of access. The purpose of ADA Title III, however, was to remedy the lack of access to places of public accommodation by individuals with disabilities. State tort law already provides relief where an individual becomes injured due to a negligent design feature. With the unavailability of compensatory damages, the pure lack of access cases are not going to juries. They are being decided exclusively by judges. And, unfortunately, the reported decision data suggests that judges are not as sympathetic to ADA Title III cases as are juries.

The lack of availability of compensatory damages therefore causes two results: (1) a limited availability for relief, and (2) judge rather than jury decisions. Not only do plaintiffs fail to obtain compensatory damages, but they often fail to prevail altogether before an unsympathetic judiciary. When CRA Title II was passed, the thinking about the judge/jury distinction was quite different. Civil Rights proponents feared that white southern juries might be unsympathetic to CRA Title II claims, so that the decision to permit only injunctive relief had the additional advantage of having the case not eligible for jury determination. The choice of only permitting injunctive relief under the law of race was considered by some civil rights advocates to be the best choice because of the problem of prejudiced juries. $^{126}$ By contrast, injunctive relief was considered to be more effective, because "the expenses involved are borne by the government, a trial by a prejudiced jury is never necessary, and the remedy is of continuing effect,

123. See Gladys Haney v. Sunnyvale Town Ctr., No. CV 762408 (Santa Clara County Super. Ct., Cal.) (Aug. 11, 1997), available in LEXIS, VERDCT Library.

124. Id.

125. In private conversations with attomeys who attended the Symposium, I learned that they had found it very difficult to get judges even to consider their client's right to relief for stigmatic injury. It might be that society's lack of recognition of the importance of accessibility to individuals with disabilities has contributed to my findings of relatively low jury awards. Those results could change someday, but, at present, there appears to be little evidence suggesting that juries would award substantial claims for lack of accessibility cases.

126. See Wright, supra note 66 , at 449. 
permitting punishment for contempt when the injunctive order is violated.", 27 Under ADA Title III, however, we usually have reason to come to the opposite conclusion since the existing data shows that juries are more likely to rule in favor of plaintiffs than are judges in bench trials. ${ }^{28}$ The limitation to purely injunctive relief not only precludes plaintiffs from obtaining compensatory damages, but also causes them to have their cases heard before judges rather than juries.

\section{Settlements}

One might argue that reported decision and verdict data offer an incomplete picture of ADA compliance because they do not include settlements. Settlement data is probably the hardest to acquire since settlements are often not made public. Nonetheless, the Department of Justice ("DOJ") reports its settlements on its web site. The web site indicates that the DOJ has attained settlements in 46 ADA Title III cases as of September 1998.

When the DOJ settles an ADA Title III case, it has leverage that is not available to private plaintiffs-it has the statutory authority to seek civil damages if it brings suit. ${ }^{129}$ Private parties can also intervene in their cases to seek damages under state law. Despite this financial leverage, the DOJ only obtained a significant civil fine of $\$ 50,000$ in one case. Of the other 16 cases in which the DOJ obtained monetary settlements, the amounts ranged from $\$ 250$ to $\$ 10,000$. Two of the fines were in the form of gift certificates of $\$ 500$ and $\$ 900$.

A typical settlement involved claimants with mobility impairments who alleged that an existing facility was not accessible although accessibility was "readily achievable." "130 Often the case was coupled with a claim that the entity failed to provide an auxiliary aid. Twelve cases involved the "readily achievable" standard; only two cases involved the more lenient standard for new construction. ${ }^{131}$

The remedies obtained by the DOJ under the readily achievable standard for existing entities were often quite significant. For example, Comfort Inn agreed to remove barriers relating to parking, ramps, and walkways; to replace emergency lights; to create accessible restrooms; to lower restaurant cash registers; to provide a lift to the swimming pools; to create accessible drinking fountains; and to create

127. $I d$.

128. However, it should be noted that even if compensatory damages became available, some plaintiffs might choose to forego that possibility and seek only injunctive relief, in order to avoid the possibility of a prejudiced jury in, for example, the HIV context.

129. See 42 U.S.C. $\S 12188$ (b)(2)(C)(i)-(ii) (1994) (providing for a civil penalty of $\$ 50,000$ for a first violation and $\$ 100,000$ for any subsequent violation).

130. See id. $\$ 12182(\mathrm{~b})(2)($ A)(iv) (1994) (providing that unlawful discrimination includes "a failure to remove architectural barriers, and communication barriers that are structural in nature, in existing facilities ... where such removal is readily achievable."); see also id. $\S 12181(9)$ (defines the term "readily achievable" as meaning "easily accomplishable and able to be carried out without much difficulty or expense.").

131. Compare ADA Title III, 42 U.S.C. \& 12183(a)(1) (1994) (new construction) with \& 12182(b)(2)(A)(iv) (existing construction). For new construction, the ADA provides that an entity must be "readily accessible to and usable by individuals with disabilities, except where an entity can demonstrate that it is structurally impracticable to meet the requirements of such subsection ...." Id. $\S 12183(\mathrm{a})(1)$. 
accessible rooms and doorways at their motels throughout the country. Similarly, Friendly Ice Cream (which was also assessed a $\$ 50,000$ fine) agreed to remove steps; widen doors; redesign vestibules and dining areas for wheelchairs; provide accessible parking, restrooms, and routes; install curb cuts; relocate telephones; and read menus to people with visual impairments at their stores throughout the country. There were also many cases with effective but inexpensive compliance, such as changing policies to permit service animals into an entity or changing policies about use of a driver's license as an exclusive form of identification.

While the DOJ settlements appear to be effective, they are few in number. Forty-six settlements in approximately six years of statutory enforcement reflects less than one settlement a month by an agency charged with national enforcement. Although it may be the case that the DOJ can attain effective enforcement in the cases it prosecutes, it is unrealistic to expect that such efforts will have much impact on the pattern of denial of accommodation that may exist in the larger society. It is hard to believe that the kinds of general problems that the DOJ found-inaccessible hotels and restaurants, improper service animal policies, and inappropriate photo identification policies-are isolated to those 46 entities.

Under the existing statutory scheme, DOJ enforcement is a theoretically important part of statutory compliance, because the DOJ is settling the pure access cases that ADA Title III was designed to remedy. With the limited financial incentives to file suit for this kind of violation (when a physical injury has not occurred), it is unrealistic to expect the private bar to take many of these cases. Yet the DOJ has only a few attorneys assigned to national enforcement under ADA Title III. In considering the ineffectiveness of Department of Justice ADA Title III enforcement, it is helpful to make a comparison with the FHA.

Under the FHA, if the Secretary of Housing determines that reasonable cause exists to believe that a discriminatory housing practice has occurred or is about to occur, the Secretary is required to issue a charge on behalf of the aggrieved person for further enforcement proceedings by the Attorney General. If the aggrieved individual elects a judicial remedy, then "the Secretary shall authorize, and not later than 30 days after the election is made the Attorney General shall commence and maintain, a civil action on behalf of the aggrieved person in a United States district court seeking relief under this subsection."132 By contrast, the aggrieved individual has the right to intervene in that lawsuit, thereby pursuing both a public and private cause of action at little expense to the aggrieved individual. Thus, when Congress so desires, it knows how to make enforcement by the Department of Justice effective for the aggrieved individual. ${ }^{133}$ The public enforcement opportunities

132. See Fair Housing Amendments Act, Pub. L. No. 100-430, \& 8(2), § 812(o), 102 Stat. 1619, 1632 (1988) (codified at 42 U.S.C. $\$ 3612(0)(1)$ (1994)).

133. From March 12, 1989 to December 6, 1993, the Department of Justice handled 293 "judicial election" cases-reasonable cause determinations from HUD in which the aggrieved party chose a judicial rather than administrative remedy. A consent decree or settlement was achieved in 171 of those cases; 12 went to trial and 86 were pending when these statistics were collected. See UnIted STATES CoMmission on Civil Rights, THE Fair Housing AMENDMENTS ACT of 1988: THE ENFORCEMENT REPORT 212, Table 11.4 (1994). These statistics would appear to 
under ADA Title III, by contrast, are quite limited, in part, due to Congress's limited allocation of resources to DOJ enforcement.

It is important to remember that when CRA II was passed, individuals who were familiar with state enforcement efforts under state civil rights statutes noted the importance of an administrative enforcement scheme for civil rights laws to be effective. ${ }^{134}$ Congress was not willing in 1964 to develop such an enforcement scheme for CRA II, but demonstrated its ability to create such an enforcement scheme for FHA in 1998. It is therefore disappointing to see Congress backpedal in 1990 and enact an administrative enforcement scheme that was obviously inadequate.

III.

\section{FILLING THE REMEDIAL GAP}

It is arguable that despite the limited relief under ADA Title III, the ADA might spur states to pass or amend their own anti-discrimination laws to provide effective remedies. Some states do have broader remedial provisions under their racial nondiscrimination laws than Congress provided under CRA Title II, which have served as an impetus for lawsuits such as the case against Denny's. However, even states with a strong commitment to anti-discrimination in the disability arena have not amended their state statutes to provide more effective relief than is available under ADA Title III. For example, Maine amended its disability antidiscrimination statute in 1995 to parallel the scope of coverage under the federal ADA. It repealed and replaced the section defining "places of public accommodation" so that its scope of coverage was identical to the coverage under federal law. ${ }^{135}$ But it left intact the relief provision already existing under Maine law for cases of discrimination brought against places of public accommodation. This provision caps relief at $\$ 10,000$ for first-time offenders, $\$ 25,000$ for second-

reflect a vigorous and effective enforcement mechanism but this enforcement scheme has its critics. Of these 292 cases, charges were filed on the basis of race ( 49 cases), family status ( 180 cases), disability ( 40 cases), sex ( 6 cases), national origin ( 3 cases), religion ( 2 cases), and combined basis (13 cases). Thus, there were virtually as many disability cases as race cases, suggesting that disability discrimination is an area of law requiring as much enforcement activity as race discrimination. Id.

Despite the evidence of significant enforcement activity on the part of DOJ, the DOJ's exercise of its enforcement authority has received some criticism. For example, the United States Commission on Civil Rights found:

Although the FHAA required DOJ to file a claim in every election, DOJ has returned a few election charges for further investigation by HUD. Although FHAA regulations provide that DOJ may consult with the General Counsel if new court decisions or new evidence affect HUD's initial reasonable cause determination, OGC finds it troubling that DOJ refuses to proceed in some cases. OGC asserts that DOJ returns elected charges when DOJ does not agree with the substantive issues involved in HUD's reasonable cause determination. However, DOJ maintains that it only returns an elected HUD charge when new information makes filing a claim inappropriate or frivolous. While DOJ acknowledges that it must support the Secretary's reasonable cause determination, DOJ argues that it must also fulfill its obligations to the Federal courts to file only sound claims.

Id. at 213-14.

134. See Bonfield, supra note 65 , at $1117-18$

135. 1995 Me. Laws 393,87 (codified as ME. REv. STAT. ANN. tit. 5, $§ 4553(8)$ ) (West Supp. 1998). 
time offenders, and $\$ 50,000$ for third-time offenders. ${ }^{136}$ While this relief is more generous than the relief available under the ADA, because the civil damages can be awarded directly to the victim of discrimination and are available without the intervention of the state attorney general, this relief is not a product of a deliberate attempt by the state to fill the enforcement gap under ADA Title III. The relief provisions found in the Maine anti-discrimination law preceded the enactment of the ADA. Thus, the passage of the ADA had an impact on the substantive law of Maine - the scope of coverage-but no impact on the relief available to victims of discrimination at places of public accommodation.

State disability law on discrimination at places of public accommodation can be divided into three categories: (1) states that do not have a state law banning discrimination at places of public accommodation on the basis of disability; (2) states that have a statute that prohibits such discrimination, but provide narrow remedies such as purely injunctive relief or a modest fine under the criminal code; and (3) states that provide broader remedies than the ADA. Table I summarizes the overall results.

The 5 states in category one do not generally offer the protections of nondiscrimination at places of public accommodation except to provide the right to use a service animal at a place of public accommodation. ${ }^{137}$ The 25 states in category two prohibit discrimination at public accommodations but provide narrow remedies. The most typical remedy provided in these states is a misdemeanor remedy; 17 of 25 states provide that violating their law against public accommodation is a misdemeanor. These misdemeanor statutes provide virtually no relief at all. As indicated in parentheses after the statutes, the misdemeanor penalty ranges from $\$ 10$ to $\$ 5,000$. Many of these states also have very antiquated statutes that cover only a subcategory of individuals with disabilities. I have marked the states that limit their coverage to individuals with visual, hearing or other physical disabilities; 12 of the 25 states in category two fit this description.

The states with the most effective remedies are listed in category three. Twenty-one states provide some form of compensatory relief. Twenty-one of 51 states (including the District of Columbia) therefore provide for reasonably effective relief beyond what ADA Title III requires.

136. Me. Rev. Stat. AnN. tit. 5, §4613(2)(B)(7) (West Supp. 1998).

137. I placed South Carolina in category one, although it appears to provide a right of access to public accommodations but no remedy other than voluntary conciliation. See supra note 138 . 
TABLE I: State PUBlic ACCOMMODATION STATUTES PROHIBITING Disability DISCRIMINATION

\begin{tabular}{|c|c|c|}
\hline $\begin{array}{c}\text { Category One } \\
\text { (No prohibition) }\end{array}$ & $\begin{array}{c}\text { Category Two } \\
\text { (Narrow remedies) }\end{array}$ & $\begin{array}{c}\text { Category Three } \\
\text { (Broad remedies) (date) }\end{array}$ \\
\hline $\begin{array}{l}\text { Oklahoma }^{138} \\
\text { South Carolina }^{139} \\
\text { Tennessee } \\
\text { Texas } \\
\text { Washington }^{142}\end{array}$ & $\begin{array}{l}\text { Alabama+(M) } \\
\text { Alaska }(\$ 500 \text { cap) } \\
\text { Arkansas }(M) \\
\text { Colorado+(\$10-300)(M) } \\
\text { Connecticut }(\$ 25-100)(M) \\
\text { District of Columbia } \\
\text { Georgia+ }+\$ 100)(M) \\
\text { Iowa+(M) } \\
\text { Kansas+(\$2000 cap)(M) } \\
\text { Maryland }(\$ 500-2500) \\
\text { Massachusetts++(\$2500 cap)(M) } \\
\text { Mississippi }+(M)(\$ 100) \\
\text { Montana+(M) } \\
\text { Nebraska+(M) } \\
\text { New Hampshire }(M) \\
\text { New Mexico+(M) } \\
\text { New York }(M)(\$ 100-\$ 500) \\
\text { North Carolina } \\
\text { North Dakota } \\
\text { Oregon }(\$ 1,000 \text { cap) } \\
\text { Pennsylvania }(M)(\$ 500 \text { cap) } \\
\text { Rhode Island } \\
\text { Utah+(M) } \\
\text { West Virginia }(\$ 5000 \text { cap) } \\
\text { Wyoming+(M)(\$750 cap) }\end{array}$ & $\begin{array}{l}\text { Arizona (1992) } \\
\text { California (1976) } \\
\text { Delaware (1996) } \\
\text { Florida +(1992) } \\
\text { Hawaii (1988) } \\
\text { Idaho + (compensatory: 1990, } \\
\text { punitive: 1997) } \\
\text { Illinois (1989) } \\
\text { Indiana (1978) } \\
\text { Kentucky }(1974) \\
\text { Louisiana }(1980) \\
\text { Maine }(\$ 10,000-\$ 50,000 \text { in penal } \\
\text { damages)(1989) } \\
\text { Michigan }(1980) \\
\text { Minnesota (1969) } \\
\text { Missouri (1986) } \\
\text { Nevada (1965) } \\
\text { New Jersey (1990) } \\
\text { Ohio (1987) } \\
\text { South Dakota (1991) } \\
\text { Vermont (1987) } \\
\text { Virginia (1985) } \\
\text { Wisconsin (1975) }\end{array}$ \\
\hline
\end{tabular}

+Definition includes individuals who have visual or auditory impairments or are otherwise physically disabled.

++Definition includes individuals who are deaf, blind or have any physical or mental disability. (M)Misdemeanor statute.

138. Oklahoma law provides that "a blind, physically handicapped, deaf or hard-of-hearing person and his or her guide, signal, or service dog or a dog trainer... shall not be denied admittance [to public facilities or public accommodations] because of such dog." OKLA. STAT. ANN. tit. 7, § 19.1(B) (West Supp. 1999).

139. South Carolina law does appear to make conduct unlawful that is already made unlawful by the ADA. See S.C. CODE $1976 \$ \S 1-13-20 ; 1-13-100$. But there appears to be little or no enforcement authority to remedy violations of any non-employment complaints. See id. at $\$ 1-13-90$ (e) (West Supp. 1998) (providing solely for voluntary conciliation with the Human Rights Commission).

140. Tennessee law prohibits discrimination on the basis of race, creed, color, religion, sex, age or national origin, but not disability. See TENN. CODE ANN. § 4-21-501 (1998).

141. Texas law provides "persons with disabilities" with "the same right as the able-bodied to the full use and enjoyment of any public facility in the state" and provides for nondiscrimination in the rent or leasing of housing. See TEX. HUM. REs. CODE ANN. $\$ 121.003$ (a) (West Supp. 1999).

142. Washington state has a public policy concerning the right of "the blind, the visually handicapped, the hearing impaired, and the otherwise physical disabled" to places of public accommodation, see WASH. REV. CODE ANN. $\$ 70.84 .010(3)(1992)$, but provides no remedy other than in the "white cane law" context, see WASH. REV. CODE ANN. § 70.84.040 (West Supp. 1999), WASH. Rev. CodE ANN. \$ 70.84.050 (West Supp. 1999); and WaSh. Rev. CodE ANN. § 70.84.070 (1992).

143. Bold-faced type indicates statute amended after 1990 to create compensatory damages.

144. Civil penal damages were first created in the Maine statute in 1971. The damages remedy has been raised over time from an original range of $\$ 100-\$ 1,000$ to the current $\$ 10,000-\$ 50,000$ cap. See ME. REV. STAT. ANN. tit. 5 , $\S$ 4613. (West 1989 \& West Supp. 1998). 
However, to the extent that gap filling exists under state law, it does not appear that the passage of the ADA has been a major factor. I have marked the states that have statutes that were amended after 1990 to include compensatory damages with boldface type. Only 6 states fit that description. California, for example, has the most generous relief provision, making it possible for plaintiffs to obtain "up to three times the amount of actual damages but in no case less than one thousand dollars $(\$ 1,000)$ and attorney's fees." A45 Although California has increased the minimum penalty several times, the provision for relief has existed since 1976. Similarly, Vermont enacted its disability discrimination statute in 1987 and provided for injunctive relief and compensatory and punitive damages. ${ }^{146}$ States' decisions to offer broader relief than the ADA generally seem to be independent of the passage of the ADA. Although many states amended their statutes after the passage of the ADA to make their definition of "public accommodation" more consistent with the ADA's definition, only six of those states broadened the relief available in their state statute at that time. There is therefore no current groundswell for state law to serve a "gap filling" function under the law of public accommodations.

By contrast, significant gap filling at the state level has occurred in the area of racial nondiscrimination statutes since the passage of CRA Title II. Four states have no statute banning race discrimination at places of public accommodation. Fifteen states have statutes that go no further than CRA Title II. Thirty-one states provide at least compensatory relief. Of these thirty-one states, eighteen took more than a decade to include compensatory damages. Table II summarizes these results.

145. CAL. Civ. CoDE $\S 54.3$ (West Supp. 1999).

146. Vt. STAT. ANN. tit. $9, \S 4506$ (1993). 
TABle II: State Statutes Prohibiting Race Discrimination at Places of PUBLIC ACCOMMODATION

\begin{tabular}{|c|c|c|}
\hline $\begin{array}{l}\text { Category One } \\
\text { (No prohibition } \\
\text { against } \\
\text { discrimination) }\end{array}$ & $\begin{array}{l}\text { No Compensatory or } \\
\text { Punitive Damages } \\
\text { (date enforcement } \\
\text { scheme established) }\end{array}$ & $\begin{array}{c}\text { Compensatory or Punitive } \\
\text { Damages (original date } \\
\text { compensatory damages } \\
\text { adopted) }\end{array}$ \\
\hline $\begin{array}{l}\text { Alabama } \\
\text { Georgia } \\
\text { Mississippi } \\
\text { North Carolina } \\
\text { Texas }\end{array}$ & $\begin{array}{l}\text { Arizona (1965) } \\
\text { Colorado (1979) } \\
\text { Connecticut (1980) } \\
\text { Idaho (1961) } \\
\text { Illinois (1989) } \\
\text { Kansas (1961) } \\
\text { Maine (1971) } \\
\text { Maryland (1963) } \\
\text { Massachusetts (1933) } \\
\text { Nebraska (1969) } \\
\text { North Dakota (1983) } \\
\text { Rhode Island (1991) } \\
\text { Virginia (1987) } \\
\text { West Virginia (1967) } \\
\text { Wyoming (1982) }\end{array}$ & $\begin{array}{l}\text { Alaska (1970) } \\
\text { Arkansas (1993) } \\
\text { California (1905) } \\
\text { District of Columbia (1977) } \\
\text { Florida (1992) } \\
\text { Delaware (1996) } \\
\text { Hawaii (1989) } \\
\text { Indiana (1978) } \\
\text { Iowa (1965) } \\
\text { Kentucky (1974) } \\
\text { Louisiana (1988) } \\
\text { Michigan (1976) } \\
\text { Minnesota (1969) } \\
\text { Missouri (1986) } \\
\text { Montana (1895) } \\
\text { Nevada (1965) } \\
\text { New Hampshire (1992) } \\
\text { New Jersey (1990) } \\
\text { New Mexico (1969) } \\
\text { New York (1965) } \\
\text { Ohio (1987) } \\
\text { Oklahoma (1968) } \\
\text { Oregon (1973) } \\
\text { Pennsylvania (1955) } \\
\text { South Carolina (1990) } \\
\text { South Dakota (1991) } \\
\text { Tennessee (1978) } \\
\text { Utah (1965) } \\
\text { Vermont (1987) } \\
\text { Washington (1973) } \\
\text { Wisconsin (1980) }\end{array}$ \\
\hline
\end{tabular}

The issue of relief, however, has a unique quality in the area of racial nondiscrimination legislation that may not translate into the area of disability nondiscrimination legislation. The choice of only permitting injunctive relief under the law of race was considered by some civil rights advocates to be the best choice because of the problem of prejudiced juries, as discussed above. Thus, state legislatures may have always been willing to create compensatory damages under their racial nondiscrimination statutes; they were not asked to do so until the jury climate became more favorably disposed to claims of race discrimination. There is little or no evidence that state legislatures that enacted legislation forbidding disability-based discrimination, but which limited the remedies to injunctive relief,

147. State names are in bold-face if the state took a decade or more after the passage of the Civil Rights Act to enact a remedial scheme that included compensatory damages. 
were willing to consider compensatory damages at the time of enactment.

Nearly every state has a statute prohibiting disability discrimination at places of public accommodation. The question is whether legislatures can be mobilized to conclude that legislative action is necessary to improve the existing statutory law. One rationale for legislative action in the disability area may be that many states have quite antiquated disability statutes, like "white cane laws," which provide for a very limited prohibition against discrimination. ${ }^{148}$ If states perceive a need to update these antiquated statutes, there is the possibility that they also may be persuaded to improve their remedial scheme more generally.

A final difficulty that may exist for the law of disability discrimination is the public perception that this is now an area that is primarily the subject of federal, not state, regulation. ${ }^{149}$ When states have amended their disability statutes, they have frequently used the federal government as a "benchmark" or limit by which to define the proper contours of a statute in this area. In the racial civil rights area, we may have once thought of the states as a laboratory for innovative legal developments, but in the disability discrimination area, we may now be expecting the federal government to be the leading laboratory. If so, the only way to spur significant change would be for the federal government to take a significant step rather than to expect the states to do so.

IV.

\section{CONCLUSION}

ADA Title III was modeled on CRA Title II, specifically borrowing its limited remedial scheme. Plaintiffs who have litigated under ADA Title III have had a reasonable chance of prevailing, but litigation also appears to be a seldom used tool, due to the limited remedies available. Settlements have occurred, and their remedies have been effective, but there is little incentive for private individuals to seek settlements unless the Department of Justice initiates an enforcement proceeding. Voluntary compliance is difficult to measure, but any casual observation of the accessibility of places of public accommodation reveals that there is much work to be done in order to attain compliance. ${ }^{150}$

148. White cane laws abrogate the common law contributory negligence per se rules when an individual who is blind is injured when not using a cane or a dog. See generally Adam A. Milani, Living in the World: A New Look at the Disabled in the Law of Torts, 48 CATH. U. L. REV. 323, 350-53 (1999). These laws do enhance the ability of individuals who are blind to travel safely, but are not a sufficient mechanism for providing the right to nondiscrimination at places of public accommodation for individuals, in general, who have disabilities. In some states, the only protection against discrimination at places of public accommodation is the white cane law. In such cases, the state needs to update its law of nondiscrimination.

149. By contrast, when the Civil Rights Act of 1964 was passed, the federal government was careful to recognize the importance of existing state laws in this area. See Wright, supra note 66, at 434 (concluding that Title II of the Civil Rights Act actually encouraged state action).

150. Each year, I have students in my disability discrimination course conduct an accessibility study of an entity covered by ADA Title III. I do not limit their choice, except by geography. Each student, every year, can find accessibility violations at the site that he or she studies. In my own personal travels, I can virtually always find accessibility problems at a site that I visit. 
The Tenth Anniversary of the ADA provides a good opportunity to assess the effectiveness of the ADA's remedies. Nearly all of the ADA Title III verdicts involved cases with a state law claim for compensatory damages under a negligence per se theory. Plaintiffs were only able to attain verdicts if they had actual physical injuries from a fall due to negligent construction. The ADA Title III cases that resulted in reported opinions or DOJ settlements did involve pure right to access issues-without the requirement of an actual physical injury-but those cases were very few in number. The DOJ's enforcement authority enhanced the relief available in those cases, but the DOJ is able to bring very few cases despite its national enforcement authority. Its enforcement authority is much more limited under ADA Title III than it is under the FHA. At a minimum, Congress should enhance DOJ enforcement authority to increase compliance with ADA Title III.

State law is also in serious need of expansion, although 21 states provide for greater relief than ADA Title III, and 6 of those states have enhanced their remedial scheme since 1990. But in general, not only do states need to enhance the relief available under their state statutes, but they need to revisit the scope of protection generally provided under state law in the area of disability discrimination. Many state statutes are woefully antiquated and in serious need of updating.

Revision of state law, however, is not an adequate ultimate solution to the remedy problem. The purpose of national legislation like the ADA is to provide a uniform and national set of anti-discrimination standards. Yet that reality has not been realized. Plaintiffs who suffer physical injuries as a result of inaccessibility may have a viable state law claim for negligence with the possibility of compensatory relief. Plaintiffs in 16 states can sue to challenge inaccessibility problems and recover more than injunctive relief under state law. And a handful of plaintiffs each year can benefit from the DOJ's enforcement efforts on their behalf. But the remaining victims of discrimination under ADA Title III have little, if any, recourse if their accessibility problems have not caused physical injury. If Congress is serious about providing access to public accommodations for all Americans, such regional differences are unacceptable.

To attain uniform enforcement, we should move toward a compensatory damage scheme under ADA Title III, borrowing from the damages scheme available under the FHA. Experience at the state level suggests that there is little reason to fear runaway juries if damages were to be expanded under ADA Title III. The very fact that we need not fear runaway juries, however, also gives pause to wonder whether we should not be even more ambitious for seeking effective remedies under ADA Title III. By permitting injunctive relief and limited compensatory relief, we still may not be giving businesses sufficient incentives to comply with ADA Title III. Businesses might calculate that it is cheaper to not comply, since statutory enforcement is unlikely to be as expensive as compliance from the date of enactment of the ADA. In other words, a business that is sued in the year 2000 for failing to comply with ADA Title III may have benefited for ten years by saving money on an auxiliary service or device. Prospectively offering 
that device and paying a modest compensatory award to an individual victim of discrimination as a result of enforcement activity may be cost effective. But if the remedial scheme required a business to pay a fine for all the years in which it did not comply with the ADA, then the failure of the business to comply with the statute may not be cost effective. The DOJ's civil fine authority provides that incentive structure but, given the DOJ's limited enforcement resources, it cannot act as a serious deterrent against unlawful conduct under ADA Title III. The FHA's mandatory enforcement scheme by the Attorney General would create a significant improvement in ADA compliance.

ADA Title III was a significant and important step in improving the lives of individuals with disabilities. It is now time to ask, however, whether we can do a better job in creating an effective enforcement scheme to achieve those aspirations. Our experience under the FHA and state disability anti-discrimination law should provide models for more effective enforcement. 